\title{
Pathogenicity of an Invasive Bacterium, Aeromonas salmonicida in Indian Major Carp, Labeo rohita - Evaluation of Immune Response Using Effective Molecular Markers
}

\author{
Subharthi Pal ${ }^{1}$, Dola Roy ${ }^{1}$, Sriparna Datta Ray ${ }^{1}$, Sumit Homechaudhuri ${ }^{1, *}$ \\ ${ }^{1}$ University of Calcutta, Department of Zoology, Aquatic Bioresource Research Laboratory, 35, Ballygunge Circular \\ Road, Kolkata, West Bengal - 700019, India.
}

\section{Article History}

Received 05 July 2019

Accepted 07 January 2020

First Online 23 January 2020

\section{Corresponding Author}

Tel.: +913324615445/284

E-mail:

sumithomechaudhuri@gmail.com

\section{Keywords}

Labeo rohita

Aeromonas salmonicida

Gene expression

Oxidative stress

Apoptosis

\begin{abstract}
Effects of Aeromonas salmonicida on the non-specific immune response, oxidative stress and subsequent cell death in liver and spleen of Labeo rohita exposed to asymptomatic dose $\left(2 \times 10^{7} \mathrm{CFU} / \mathrm{mL}\right)$ of pathogen were studied. Evaluation of in vivo non-specific immunity via Nitro blue tetrazolium (NBT) reduction assay, myeloperoxidase (MPO) assay and serum bactericidal activity assay exhibited significant alterations among infected fishes, indicating temporary surge of innate immune responses. Considerable cell death and damage was observed in the histopathological analysis of liver and spleen in the infected fishes. Flow cytometric analysis by FITC-Annexin V/PI conclusively indicated triggering of apoptotic cell death in both organs. Relative expression of pro-inflammatory cytokine (TNF $\alpha$ ) gene, antimicrobial protein producing genes (Lysozyme $\mathrm{C}$ and Lysozyme $\mathrm{G}$ ) and apoptosis effector molecule (Caspase 3 ) gene were increased significantly both in liver and spleen of $A$. salmonicida treated fishes. In conclusion, infection with $A$. salmonicida at asymptomatic level resulted in severe oxidative stress that, caused apoptotic cell death. Since facultative pathogen eradication is not possible in open water or flowthrough aquaculture systems, this remains a crucial area of scientific research and the results obtained in the present study might provide better understanding of prophylactic, diagnostic and therapeutic measures during aquaculture.
\end{abstract}

\section{Introduction}

Aquaculture industries worldwide frequently suffer heavy financial losses that threaten their growth and sustainability, mainly due to uncontrolled microbial diseases resulting in mass mortalities (Almeida et al., 2009). The most significant factors out of all the microbial diseases are bacterial (Zorilla et al., 2003) and viral (Crane, \& Hyatt, 2011). The study of fish diseases requires a wide knowledge, not only of the potential pathogens, but also of the environmental constraints and special adaptations, which govern the inflammatory and immune responses of fishes. Expedient recognition, treatment and prevention of fish diseases are essential for the improvement of fish culture and subsequent increase in fish resources. The increased frequency of international transfer of exotic fish species in the last few decades have led to introduction of numerous novel and exotic pathogens in many countries (Arthur, 2005). In the Indian perspective, one such key invasive bacterial pathogen is Aeromonas salmonicida. According to Evenberg and Lugtenberg (1982) the virulence factor of A. salmonicida is a protein layer, composed of $50 \mathrm{kD}$ protein (A-protein) known as A-layer. Although it was previously reported to cause disease exclusively in the salmonids, several cases of $A$. salmonicida infections 
have been reported in non-salmonids (Bernoth, Ellis, Midtlyng, Olivier, \& Smith, 1997; Arkoosh et al. 2004; Cipriano, \& Bullock, 2001; Martinez Murcia et al. 2005). Currently India is the largest producer of the carps, Labeo rohita, Catla catla and Cirrhinus mrigala, which contribute to nearly one third of its total fish production (FAO, 2018). However, during intensification of aquaculture system, outbreaks of disease have become one of the major hurdles in achieving increased production. Although Aeromonads primarily cause gross, irreversible damage, fishes that survive the initial disease outbreaks are recognized as carriers of the disease and effectively continue to infect the remaining population without exhibiting signs of infection. Therefore, it is essential to develop of multiple biomarker approach for early detection at sub-clinical state or at carrier state, in order to adopt suitable preventive, health management measures to reduce the damage caused by $A$. salmonicida is being increasingly felt by Indian hatchery operators. Previous studies have indicated that the disease resistance in fish species is correlated with innate immune parameters, which probably affect the inherent capacity of pathogen resistant fish before the specific immune response act in a multifactorial approach so as to prevent bacterial colonization after invasion within the body (Sahoo et al., 2008; Reyes et al., 2008; Rodríguez, Novoa, \& Figueras, 2008). Several authors have documented such changes in innate as well as in adaptive immune parameters in fish exposed to different pathogens (Raida, \& Buchmann, 2008; 2009; Mohanty, \& Sahoo, 2010).

The objective of this present study was to provide an in depth understanding of the various aspects of the immune system functioning in L. rohita, post infection with a pathogenic strain of $A$. salmonicida, particularly at an asymptomatic carrier stage. The analysis of different immune parameters, at molecular and cellular levels, targeted in the current study might also act as important tools for disease prevention, control and management of carp farming.

\section{Materials and Methods}

\section{Bacterial Culture Collection and Dosage Preparation}

The bacterial strain used in this study, Aeromonas salmonicida subsp. salmonicida (ATCC 33658) was obtained from American Type Culture Collection, USA. After receiving it as a lyophilized culture it was subsequently revived by adding Tryptone soy broth (TSB) and transferring the rehydrated culture to a Trypticase soy agar (TSA) medium and incubated at $22^{\circ} \mathrm{C}$ for $48 \mathrm{~h}$. Consequently, streak plate method was followed to get isolated bacterial colonies on selective Coomasie Brilliant Blue Agar (CBB Agar) which resulted in bluish colonies suggesting the bacterial strain to be $A$ layer positive. For dosage preparation, the bacterial strain was cultured in TSB and incubated at $22^{\circ} \mathrm{C}$ for 48 hours followed by centrifugation at $5000 \times \mathrm{g}$ for $5 \mathrm{~min}$ and washing in $0.85 \% \mathrm{NaCl}$. The strain was enumerated by correlating the OD value taken at $600 \mathrm{~nm}$ of the growing culture with the corresponding colony forming units (CFU) obtained by spread plate dilution method (Ref: OD $600_{\mathrm{nm}} 1=2 \times 10^{9} \mathrm{CFU} / \mathrm{mL}$ ) following Pal and Pradhan (1990).

\section{Fish Acclimatization and Maintenance}

Labeo rohita fingerlings $(30.91 \pm 2.03 \mathrm{~g}$ and $15.26 \pm 0.81 \mathrm{~cm}$ ) were obtained from a local fish farm in Kolkata, West Bengal, India. Ten fishes were held in each glass aquarium $(60 \mathrm{~cm} \times 30 \mathrm{~cm} \times 30 \mathrm{~cm})$ in the animal house facility and were acclimatized for seven days. Fish were fed with tubifex and artemia. Dissolved oxygen (DO), ammonia and $\mathrm{pH}$ were regularly checked throughout the experiment. Dissolved oxygen and ammonia were monitored every week, ranging from 5.5 to $7.6 \mathrm{mg} \mathrm{O}_{2} / \mathrm{L}$ and 0.5 to $1 \mathrm{ppm}$ respectively. The $\mathrm{pH}$ ranged from 7.5 to 8.5 throughout the experimental period and water temperature was maintained at $25 \pm 2^{\circ} \mathrm{C}$.

\section{Asymptomatic Carrier State Dose Determination for A. salmonicida}

The fishes were injected intra-peritoneally (i.p.) with $A$. salmonicida starting from higher doses $\left(5 \times 10^{8}\right.$ $\mathrm{CFU} / \mathrm{ml})$ up to subsequent lower doses $\left(2 \times 10^{6} \mathrm{CFU} / \mathrm{ml}\right)$ until any external symptomatic lesions of the diseases were observed. Bacterial doses for $A$. salmonicida, chosen for experimental challenge studies starting from higher to lower range were: $5 \times 10^{8} \mathrm{CFU} / \mathrm{ml}, 3 \times 10^{8}$ $\mathrm{CFU} / \mathrm{ml}, 2 \times 10^{8} \mathrm{CFU} / \mathrm{ml}, 5 \times 10^{7} \mathrm{CFU} / \mathrm{ml}, 3 \times 10^{7} \mathrm{CFU} / \mathrm{ml}$, $2 \times 10^{7} \mathrm{CFU} / \mathrm{ml}, 5 \times 10^{6} \mathrm{CFU} / \mathrm{ml}, 3 \times 10^{6} \mathrm{CFU} / \mathrm{ml}, 2 \times 10^{6}$ $\mathrm{CFU} / \mathrm{ml}$. The haematological and serum biochemical parameters were then analyzed in fishes injected with the lowest dose of bacterial pathogen at 7 days post infection (DPI), which resulted in no visible morphological symptoms of the disease but exhibited significant alterations in the haematological and biochemical parameters in comparison to control fishes, which in terms indicated successful establishment of the bacterial infection within the fish body essentially at an asymptomatic level i.e. successful production of carrier stages in the L. rohita fingerlings.

\section{Experimental Setup}

Fishes were injected intraperitoneally (i.p.) with a carrier state dose $\left(2 \times 10^{7} \mathrm{CFU} / \mathrm{mL}\right)$ of $A$. salmonicida, made up in PS (working volume: $0.5 \mathrm{~mL} 100 \mathrm{gm} / \mathrm{body}$ weight of fish). A total number of 180 fishes were used in the course of the overall experiment to study the different parameters. Fishes were divided into three groups as follows: negative control (without any injection), sham operated control (i.p. injection of sterile culture media) and $A$. salmonicida treated. For every group there were 6 replicates, each containing 10 fishes. 
The potential health parameters chosen for the study were recorded on the $7^{\text {th }}, 14^{\text {th }}$ and $21^{\text {st }}$ day of exposure and compared with corresponding sham-injected control groups. The subsequent studies at cellular and molecular level were performed at 7 DPI depending upon the maximum sensitivity of the health parameters (mentioned afterwards).

\section{Haematological and Serum Biochemical Studies}

All the haematological parameters were determined following Dacie and Lewis (1984). The corpuscular values viz. Mean Corpuscular Volume (MCV) (fl), Mean Cell Haemoglobin (MCH) (pg) and Mean Corpuscular Haemoglobin Concentration (MCHC) (g/dl) were calculated from primary haematological data. Total serum protein (gm\%) and serum Glucose $(\mathrm{mg} / 100$ $\mathrm{ml}$ ) was measured by UV-VIS Spectrophotometer (UV 1700 Pharmaspec, Shimadzu) following Biuret's method and $\mathrm{O}$ - toludine method as per the protocols mentioned in the Diagnostic Kits obtained from Nice (Nice Chemicals Pvt. Ltd., Cochin, India).

\section{Histolopathology of Liver and Spleen:}

Sham injected control and A. salmonicida treated fishes were dissected aseptically and liver and spleen were carefully fixed in Neutral Formalin buffer for 24 hours. Then, the tissues were dehydrated in upgraded alcoholic series, immersed in cedar wood oil followed by embedding in molten paraffin (melting point: $56-58^{\circ} \mathrm{C}$ ). Serial sections were cut at 5-7 $\mu \mathrm{m}$ and stained with Haematoxylin - Eosin following Deivasigamani (2008). Finally, photomicrographs were taken in Olympus BX 51 compound microscope under oil immersion.

\section{Nitro Blue Tetrazolium (NBT) Reduction Assay}

NBT assay was determined following GómezOchoa, Sabate, Homedes, and Ferrer, (2012). Blood smears were drawn on glass slides and stained with Wright stain for 2 minute and subsequently with Giemsa for 1 minute and eventually rinsed with tap water. Finally, the slides were air dried and mounted with Dibutylphthalate Polystyrene Xylene (DPX) and observed under light microscope $(45 \mathrm{X})$ to measure the percentage of cells containing black formazan deposits.

\section{Myeloperoxidase (MPO) Activity in Neutrophil Population}

Comparison of MPO activity in neutrophil of control and $A$. salmonicida infected $L$. rohita was analyzed by measuring the MPO activity in the neutrophil population using the Neutrophil Myeloperoxidase activity assay kit (Cayman Chemical) (Prokopowicz et al., 2012). The samples were loaded onto 96 well plate according to the kit and the blue color yielded due to reaction of $3,3^{\prime}, 5,5^{\prime}$-tetramethyl benzidine (TMB) with MPO was observed at an absorbance of $650 \mathrm{~nm}$ using ELISA plate reader.

\section{Serum Bactericidal Activity Assay}

Qualitative and qualitative evaluation of serum bactericidal activity was determined following Pal, Datta Roy and Homechaudhuri, (2016). Serum was collected from both control and $A$. salmonicida treated fish after 7 days of exposure.

\section{Flow Cytometric Analysis}

Single cell suspensions were prepared from liver and spleen separately, following Datta Ray and Homechaudhuri (2014) with slight modifications and the following assays were performed. For each set, a total of 10,000 even counts were taken. All flow cytometric data were analyzed using BD Accuri C6 Software.

\section{Annexin V-FITC / PI Assay}

Nature of cell death in liver and spleen was ascertained using FITC conjugated Annexin $\mathrm{V}$ and Propidium iodide following Datta Ray and Homechaudhuri (2014) with slight modifications.

\section{Gene Expression Analysis of Target Genes}

The relative levels of expression of TNF- $\alpha$, Caspase 3, Lysozyme $\mathrm{C}$ and Lysozyme $\mathrm{G}$ were analyzed by densiometry using ImageJ software (USNIH, USA). For analysis of gene expression, total RNA was extracted from 50-100 mg tissue samples, taken from sham injected control and $A$. salmonicida treated fishes using Takara RNA - Iso Plus following a standard protocol (Sambrook, Russell, \& Russell, 2001). Total RNA concentration and purity was observed by measuring OD at 260 and $280 \mathrm{~nm}$ using Microdrop (Multi Skan Go, Thermoscientific, USA). Total RNA ( $5 \mu \mathrm{g}$ ) was used for first strand cDNA synthesis using thermocyler (Applied Biosystems). RNA primer reaction mixture was prepared in a microtube using Random Hexamers $(50 \mu \mathrm{M})$, dNTP mixture (10 mM each), template RNA and RNase free $\mathrm{dH} 2 \mathrm{O}$ following protocol as provided in the PrimeScript c-DNA Synthesis Kit - 6110A (Takara Bio Inc). The cDNA samples were kept at $0^{\circ} \mathrm{C}$ for further use. Multiple primers were designed for the genes of interest using Fast PCR software (Informer Technologies, Inc.). Standard desalted primers were custom made from Integrated DNA Technologies (IDT). The sequences of the chosen primers are given below in Table 1 . The ratios of target gene/ $\beta$-Actin product were subsequently calculated after subtraction of the background pixel intensity of each gene of interest and used to assess the differences in expression levels between the control and the infected samples. 


\section{Re-Isolation and Detection of $\boldsymbol{A}$. salmonicida}

Presumptive identification of bacterial pathogen was evaluated by several biochemical tests. Tissue homolysate prepared from liver of $A$. salmonicida challenged fish was plated onto Coomassie brilliant blue (CBB) agar, MacConkey and Tryticase soy agar (TSA). Genomic DNA was isolated from the bacterial colonies and subsequently PCR was performed for confirmation of the bacterial strain. Four pairs of primers were used viz. AP1/AP2 (Gustafson \& Thomas, 1992), PAAS1/PAAS2 (O'Brien et al., 1994), MIY1/MIY2 (Miyata, Inglis, \& Aoki, 1996) \& 16S rRNA (Dorsch, \& Stackebrandt, 1992). After gel electrophoresis the PCR products were observed under an UV transilluminator and the results obtained were analyzed by Gel Doc, BioRad Quality One Software, Version 4.6.5. Standard desalted primers were custom made from Integrated DNA Technologies (IDT). The sequences of the chosen primers are given in Table 2.

\section{PCR Reaction Using the Bacterial Genomic DNA}

PCR reaction was carried out after bacterial genomic DNA isolation. $2.5 \mu \mathrm{l}$ of 10X Taq Buffer (PCR buffer) was mixed with $4 \mu \mathrm{l}$ of dNTP mixture (dATPs, dTTPs, dGTPs, gCTPs) in PCR tubes. $1 \mu \mathrm{l}$ of forward primer and $1 \mu \mathrm{l}$ of reverse primer specific for different genes were then added into thesample followed by addition of $0.5 \mu \mathrm{l}$ of Taq DNA polymerase. Finally, volume make up was made up by miliQ water to make the final volume of PCR mixture to $25 \mu$ l. The initial denaturing temperature, PCR cycle conditions (denaturing temperature, annealing temperature, temperature during extension) and final extension, for screening the different genes, were determined by trial and error methods after multiple trials using a range of temperatures from $90-95^{\circ} \mathrm{C}$ (for denaturation), $45-60^{\circ} \mathrm{C}$ (for annealing) and $65^{\circ} \mathrm{C}$ to $75^{\circ} \mathrm{C}$ (for extension). The best results were obtained at the specific temperatures and timings mentioned in Table 3.

Table 1. Primer sequences for selected genes

\begin{tabular}{lcc}
\hline Gene & Sequence $\left(5^{\prime}-3^{\prime}\right)$ & Amplicon size (bp) \\
\hline$\beta$-Actin & F- GACTTCGAGCAGGAGATGG & 138 \\
TNF- $\alpha$ & R- CAAGAAGGATGGCTGGAACA & 377 \\
Caspase 3 & F- GGACTACCAGCTGTTGTGCAT & \\
& R- GCCACCATCGACTGCAAT & 285 \\
Lysozyme C & F- ATGAACGGAGACTGCGTGGA & 244 \\
& R- TGGTGAGCATCGAGACAATGCAGG & \\
Lysozyme G & F- CGCTGTGATGTTGTCCGTATCTTC & 360 \\
& R- GTAACTTCCCCAGGTATCC & \\
\hline
\end{tabular}

Table 2. Primer sequences of selected genes for identification of $A$. salmonicida

\begin{tabular}{lcc}
\hline Gene & Sequence $\left(5^{\prime}-3^{\prime}\right)$ & Amplicon size (bp) \\
\hline 16 r rRNA & F- GAGTTTGATCCTGGCTCAG & 1465 \\
PAAS1/PAAS2 & R- TACGGYTACCTTGTTACGACTT & 423 \\
AP1/AP2 & F- CGTTGGATATGGCTCTTCCT & \\
& R- CTCAAAACGGCTGCGTACCA & 421 \\
MIY1/MIY2 & F- GGCTGATCTCTTCATCCTCACCC & 512 \\
& R- CAGAGTGAAATCTACCAGCGGGTGC & \\
\hline
\end{tabular}

Table 3. PCR conditions of selected genes for detection of $A$. Salmonicida

\begin{tabular}{|c|c|c|c|c|c|}
\hline \multirow{2}{*}{ GENE } & \multirow{2}{*}{ Initial denaturation } & Denaturation & Annealing & Strand Elongation & \multirow{2}{*}{ Final extension } \\
\hline & & \multicolumn{3}{|c|}{ PCR cycles * } & \\
\hline PAAS1/PAAS2 & $\begin{array}{c}95^{\circ} \mathrm{C} \\
2 \text { minutes }\end{array}$ & $\begin{array}{c}94^{\circ} \mathrm{C} \\
2 \text { minutes }\end{array}$ & $\begin{array}{c}57^{\circ} \mathrm{C} \\
30 \text { seconds }\end{array}$ & $\begin{array}{c}72^{\circ} \mathrm{C} \\
1 \mathrm{~min} 30 \mathrm{sec}\end{array}$ & $\begin{array}{c}72^{\circ} \mathrm{C} \\
3 \text { minutes }\end{array}$ \\
\hline AP1/AP2 & $\begin{array}{c}94^{\circ} \mathrm{C} \\
2 \text { minutes }\end{array}$ & $\begin{array}{c}94^{\circ} \mathrm{C} \\
15 \text { seconds }\end{array}$ & $\begin{array}{c}57^{\circ} \mathrm{C} \\
30 \text { seconds }\end{array}$ & $\begin{array}{c}72^{\circ} \mathrm{C} \\
1 \mathrm{~min} 30 \mathrm{sec}\end{array}$ & $\begin{array}{c}72^{\circ} \mathrm{C} \\
3 \text { minutes }\end{array}$ \\
\hline MIY1/MIY2 & $\begin{array}{c}94^{\circ} \mathrm{C} \\
2 \text { minutes }\end{array}$ & $\begin{array}{c}94^{\circ} \mathrm{C} \\
30 \text { seconds }\end{array}$ & $\begin{array}{c}58^{\circ} \mathrm{C} \\
1 \mathrm{~min} 30 \mathrm{sec}\end{array}$ & $\begin{array}{c}68^{\circ} \mathrm{C} \\
1 \mathrm{~min} 30 \mathrm{sec}\end{array}$ & $\begin{array}{c}68^{\circ} \mathrm{C} \\
3 \text { minutes }\end{array}$ \\
\hline $16 \mathrm{~S}$ rRNA & $\begin{array}{c}94^{\circ} \mathrm{C} \\
2 \text { minutes }\end{array}$ & $\begin{array}{c}94^{\circ} \mathrm{C} \\
30 \text { seconds }\end{array}$ & $\begin{array}{c}49^{\circ} \mathrm{C} \\
30 \text { seconds }\end{array}$ & $\begin{array}{c}72^{\circ} \mathrm{C} \\
1 \mathrm{~min} 15 \mathrm{sec}\end{array}$ & $\begin{array}{c}72^{\circ} \mathrm{C} \\
3 \text { minutes }\end{array}$ \\
\hline
\end{tabular}

* Number of PCR cycles for each reaction: 30 cycles 


\section{Statistical Analysis}

Means and Standard Error (S.E.) of the means were calculated from the whole range of data following Zar (1999). All data obtained were analysed using Student's t-test $(P<0.05$ as significant level). Test of homogeneity of variances by Levene statistics was performed for all the data with respect to different parameters observed $(P<0.05$ as significant level). Statistical calculations were performed using SPSS Statistics 17.0.

\section{Results}

Haematological parameters viz. total leucocyte count, MCV and $\mathrm{MCH}$ (Figure 1) and serum biochemical parameters viz. total serum protein and serum glucose level (Figure 2 ) increased significantly $(P<0.05)$ after $A$. salmonicida infection at $7 \mathrm{DPI}, 14 \mathrm{DPI}$ and $21 \mathrm{DPI}$ respectively while $\mathrm{MCHC}$ value was observed to be decreased significantly $(\mathrm{P}<0.05)$ in comparison to control fishes (Figure 1). The changes in all these values were most prominent at $7 \mathrm{DPI}$ compared to $14 \mathrm{DPI}$ and 21 DPI. Percentage of phagocytic cells with formazan deposition in the blood of fishes infected with $A$. salmonicida $(10.45 \pm 0.48)$ increased significantly $(P<0.05)$ compared to SHAM operated control fishes $(4.89 \pm 0.29)$ after 7 days of exposure period (Figure 3 ) along with significant $(P<0.05)$ increase in Myeloperoxidase (MPO) activity in the neutrophil population of blood isolated from $A$. salmonicida infected fishes (7.54E-06 $\pm 9.6 \mathrm{E}-07)$ in comparison to SHAM operated control fishes (3.08E-06 $\pm 9.6 \mathrm{E}-07)$ (Figure 4).
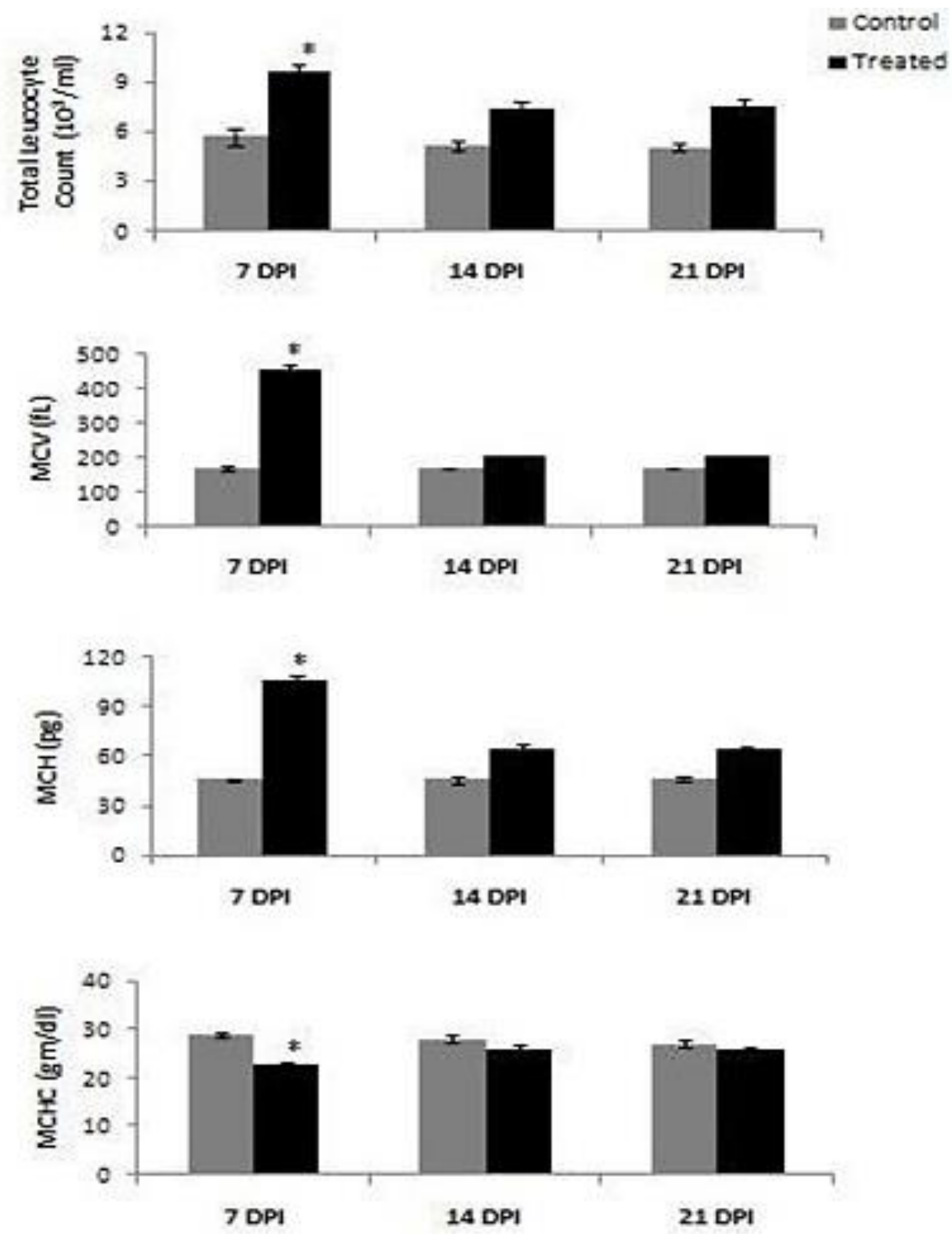

Figure 1. Total leucocyte count, $\mathrm{MCV}, \mathrm{MCH}$ and $\mathrm{MCHC}$ of control and infected $L$. rohita after 7, 14, 21 days post infection with $A$. salmonicida. * Significant $(\mathrm{P}<0.05)$. 
Relative gene expression analysis of TNF $\alpha$ gene was estimated using semi quantitative reverse transcriptase PCR after isolation of total RNA from liver and spleen of control and $A$. salmonicida infected $L$. rohita fishes. The ratios of TNF $\alpha$ / $\beta$-Actin product were subsequently calculated by densiometry using ImageJ software. A significant increase $(P<0.05)$ in the expression of TNF $\alpha$ was observed in $A$. salmonicida infected fish liver $(1.45 \pm 0.11)$ and spleen $(1.18 \pm 0.17)$ compared to liver $(0.49 \pm 0.04)$ and spleen $(0.25 \pm 0.07)$ of SHAM operated control fishes (Figure 5).
At 7 DPI fish serum was analyzed for bactericidal activity by counting CFU survivors. The results were expressed in two ways: the first one shown in Figure 6, expressed in CFU values, and the second one in Figure 7 expressed in serum bactericidal activity [1- CFU/positive (\%)]. The positive group (serum free) displayed the highest values, indicated by the largest bacterial growth, this result was expected once there was no serum to destroy bacteria, however in control and treated groups, the bacterial growth was reduced because of bactericidal ability in serum (Figure 6). Figure 7
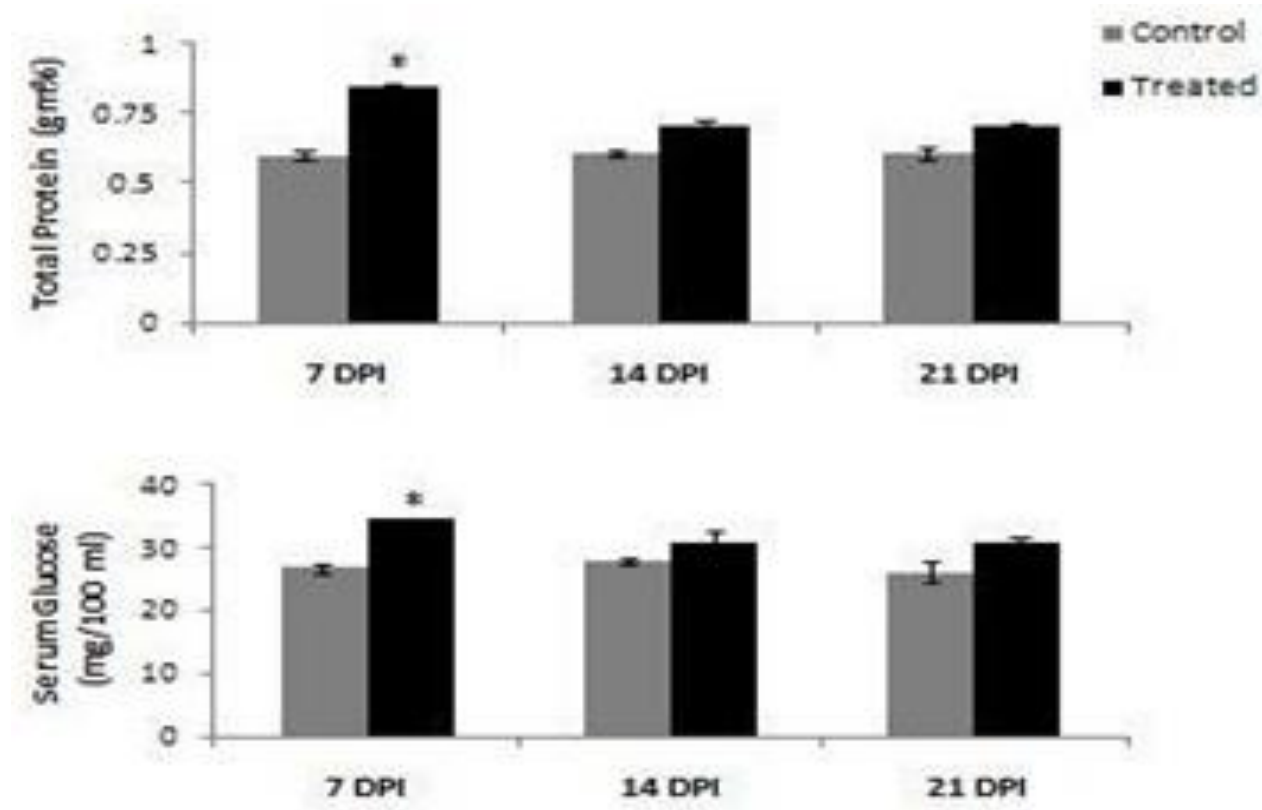

Figure 2. Total serum protein and serum glucose level of control and infected $L$. rohita after 7, 14, 21 days post infection with $A$. salmonicida. * Significant $(\mathrm{P}<0.05)$.

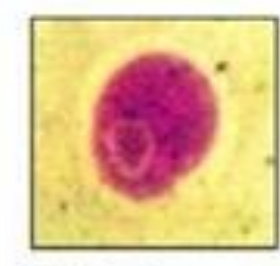

Cell wio formazan deposition

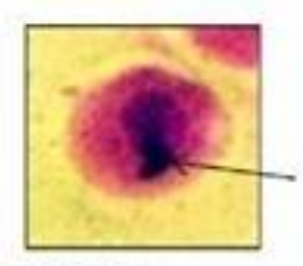

Cell with formazan deposition

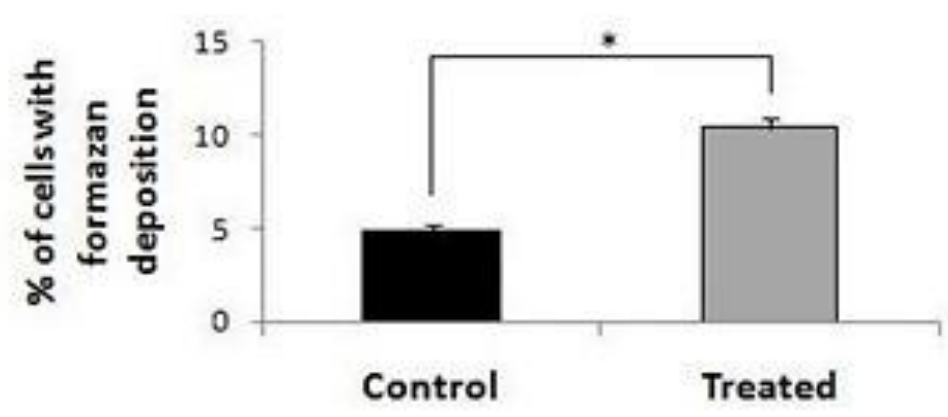

Figure 3. Percentage of phagocytic cells with formazan deposition in control and A. salmonicida infected L. rohita. ${ }^{*}$ Significant $(P<0.05)$. 


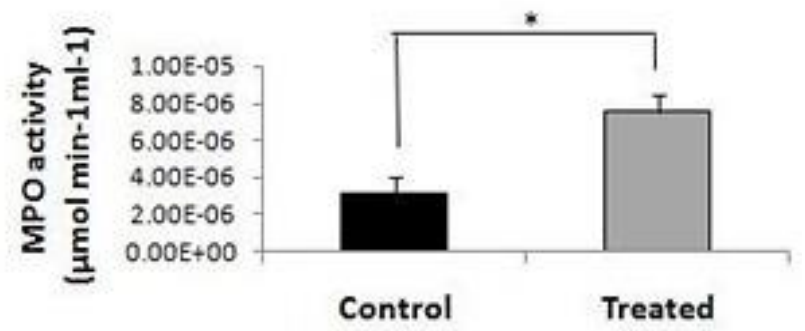

Figure 4. Determination of MPO activity in neutrophil of control and A. salmonicida infected L. rohita. ${ }^{*}$ Significant $(\mathrm{P}<0.05)$.
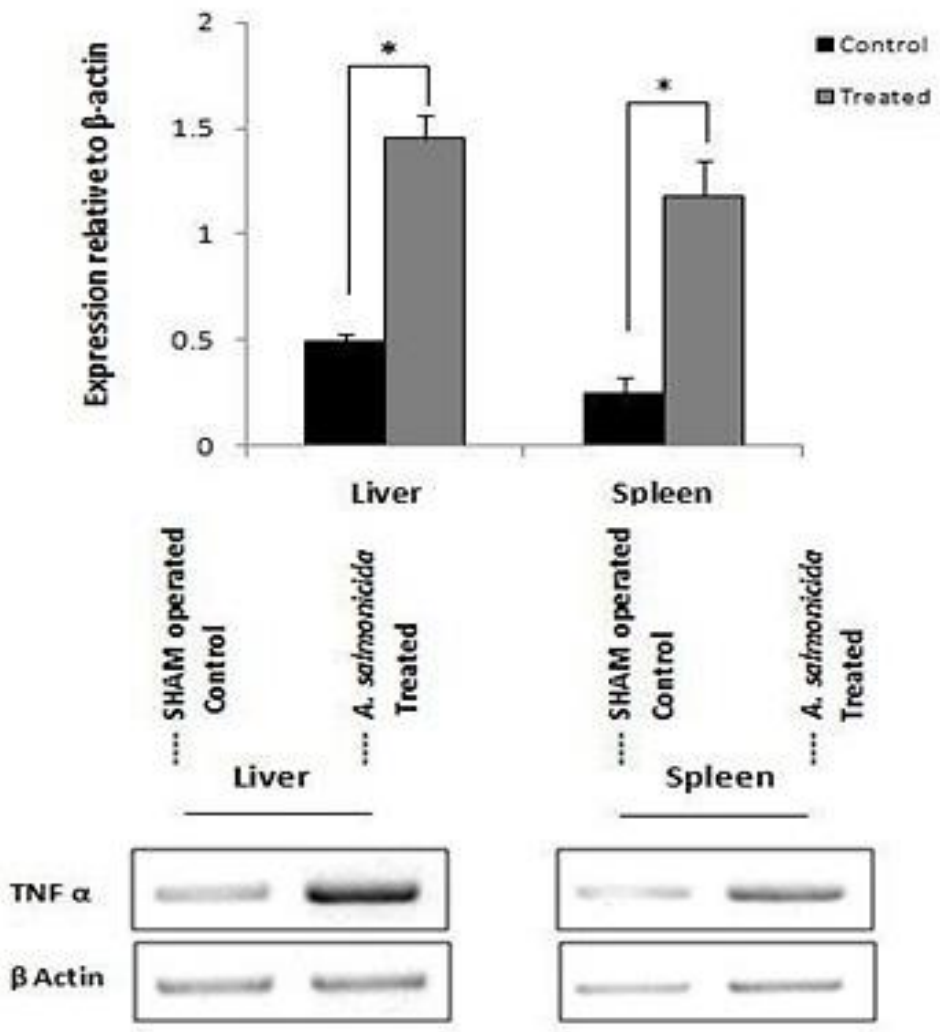

Figure 5. Differential Expression of TNF $\alpha$ in liver and spleen of SHAM operated control and A. salmonicida infected L. rohita. *Significant $(P<0.05)$.

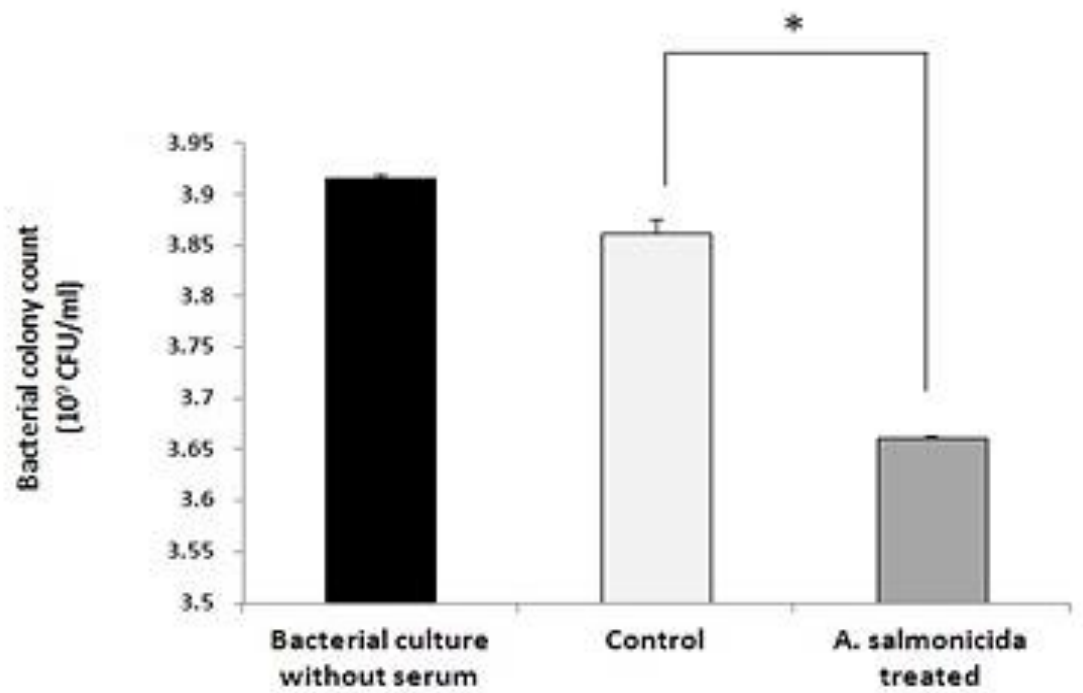

Figure 6. Bacterial colony count $(\mathrm{CFU} / \mathrm{ml})(\mathrm{Mean} \pm \mathrm{SE})$ after adding serum from SHAM operated control and A. salmonicida challenged $L$. rohita by spectrophototometric analysis. (Ref: OD $600 \mathrm{~nm} 1=2 \times 10^{9} \mathrm{CFU} / \mathrm{ml}$ ). 
represents the serum bactericidal activity of $L$. rohita after $A$. salmonicida challenge. In that, the positive group (serum free) displayed zero activity once there was no serum, but in the control and treated groups, the bacterial activity increased significantly $(P<0.05)$, indicated by the higher serum bactericidal activity profile (Figure 7). Serum bactericidal activity was also studied qualitatively, by adding serum drops from control and A. salmonicida challenged fish onto soft agar overlay mixed with $A$. salmonicida $\left(3.92 \times 10^{9} \mathrm{CFU} / \mathrm{ml}\right)$ after incubating at $25^{\circ} \mathrm{C}$ overnight and subsequently observing the zones of inhibition (Figure 8) around each drop (one drop per quadrant). Zones created by serum from treated fish (Figure 8B) appear significantly larger than the zones created by serum from control fish (Figure 8A).

A significant $(P<0.05)$ increase was observed in the expression of Lysozyme C (liver 2.08 \pm 0.24 ; spleen (3.05 \pm 0.11 ) and Lysozyme $G$ (liver $1.27 \pm 0.31$; spleen $1.04 \pm 0.26)$ among $A$. salmonicida infected fishes compared to SHAM operated control fishes in liver and spleen (Figure 9 and Figure 10) for Lysozyme C (liver

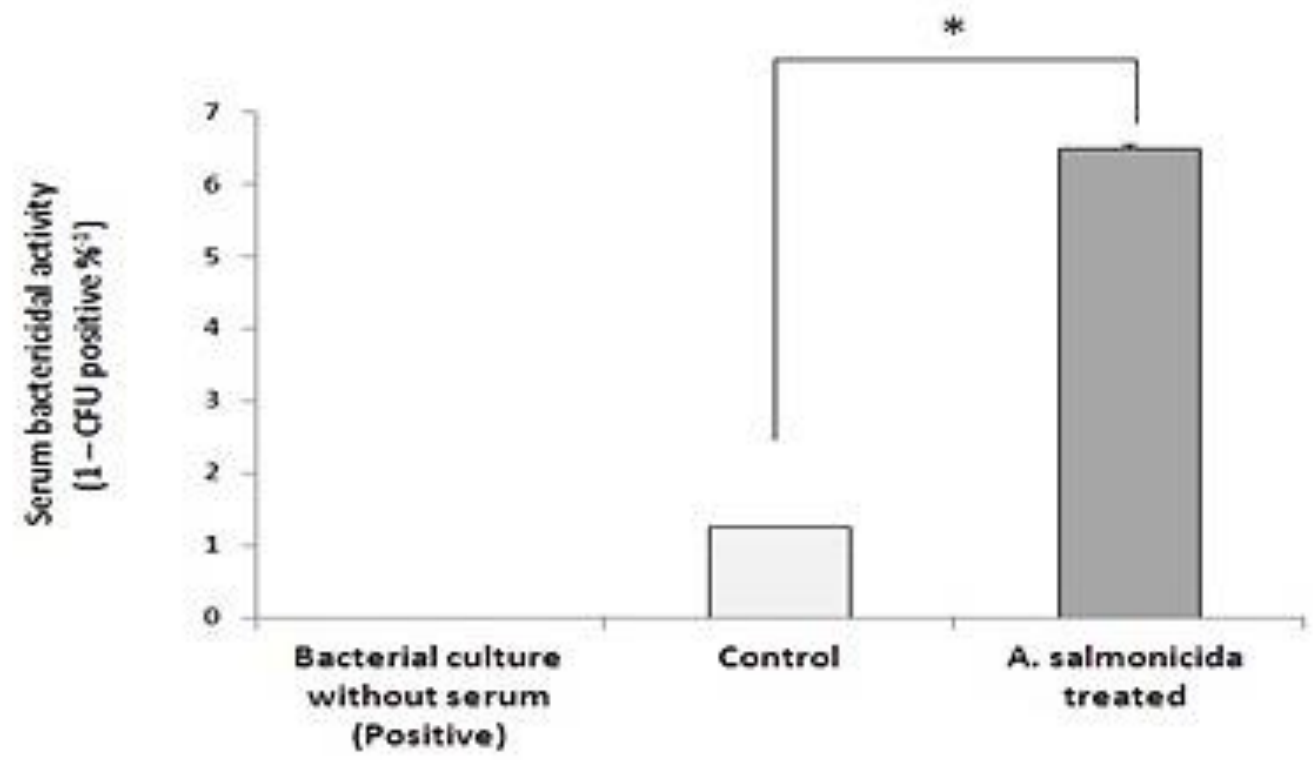

Figure 7. Serum bactericidal activity in L. rohita (1-CFU/positive \%) after challenge withA. salmonicida and in SHAM operated control samples after 7 days of exposure.

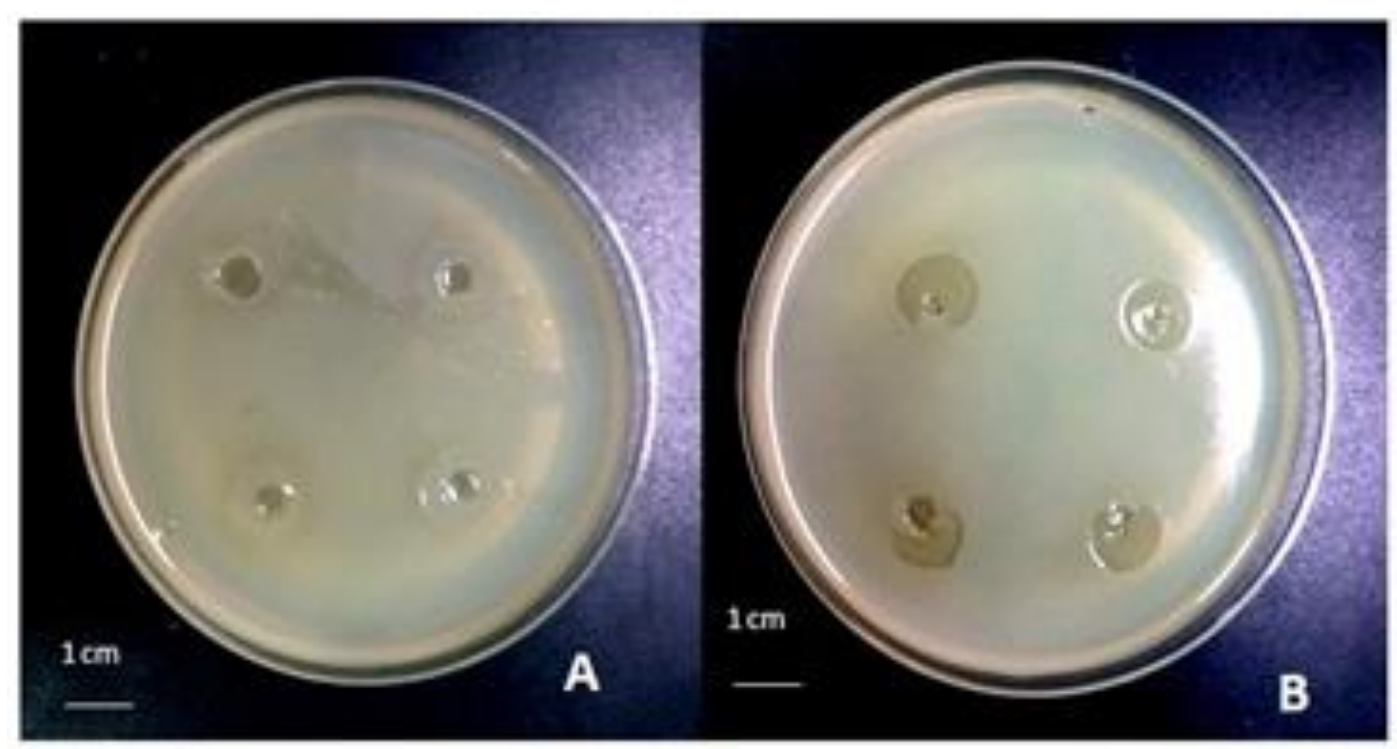

Figure 8. Observation of zones of bacterial inhibition after adding serum drops in soft agar overlay containing bacterial culture $\left(3.92 \times 10^{9} \mathrm{CFU} / \mathrm{ml}\right)$ after 24 hours incubation at $25^{\circ} \mathrm{C}$. Fig $8 \mathrm{~A}$ showing no inhibition of bacterial growth around serum drops from SHAM operated control samples and Fig $8 \mathrm{~B}$ showing zone of bacterial inhibition around serum drops from A. salmonicida challenged $L$. rohita at 7 days post infection. 

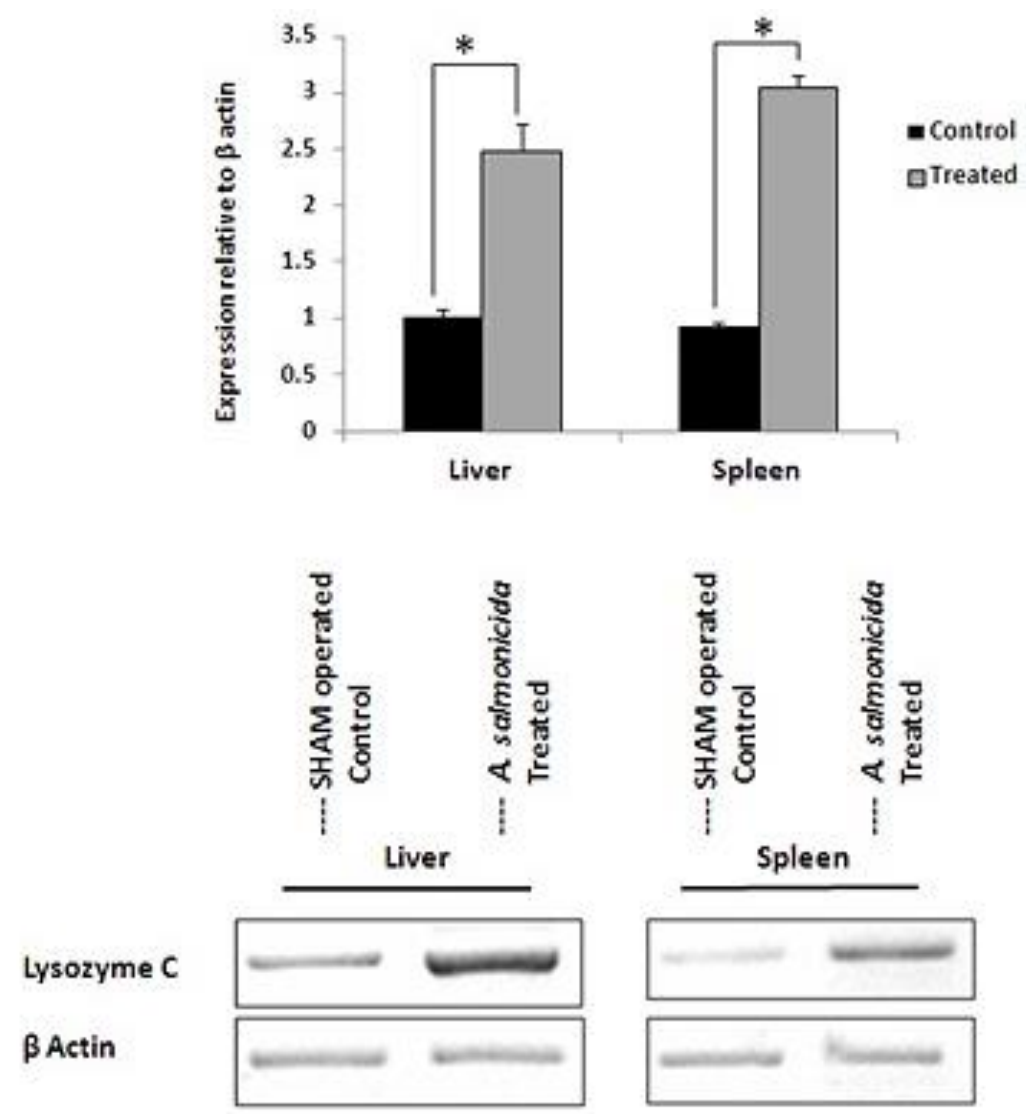

Figure 9. Differential Expression of Lysozyme $C$ in liver and spleen of SHAM operated control and $A$. salmonicida infected $L$. rohita. *Significant $(\mathrm{P}<0.05)$.
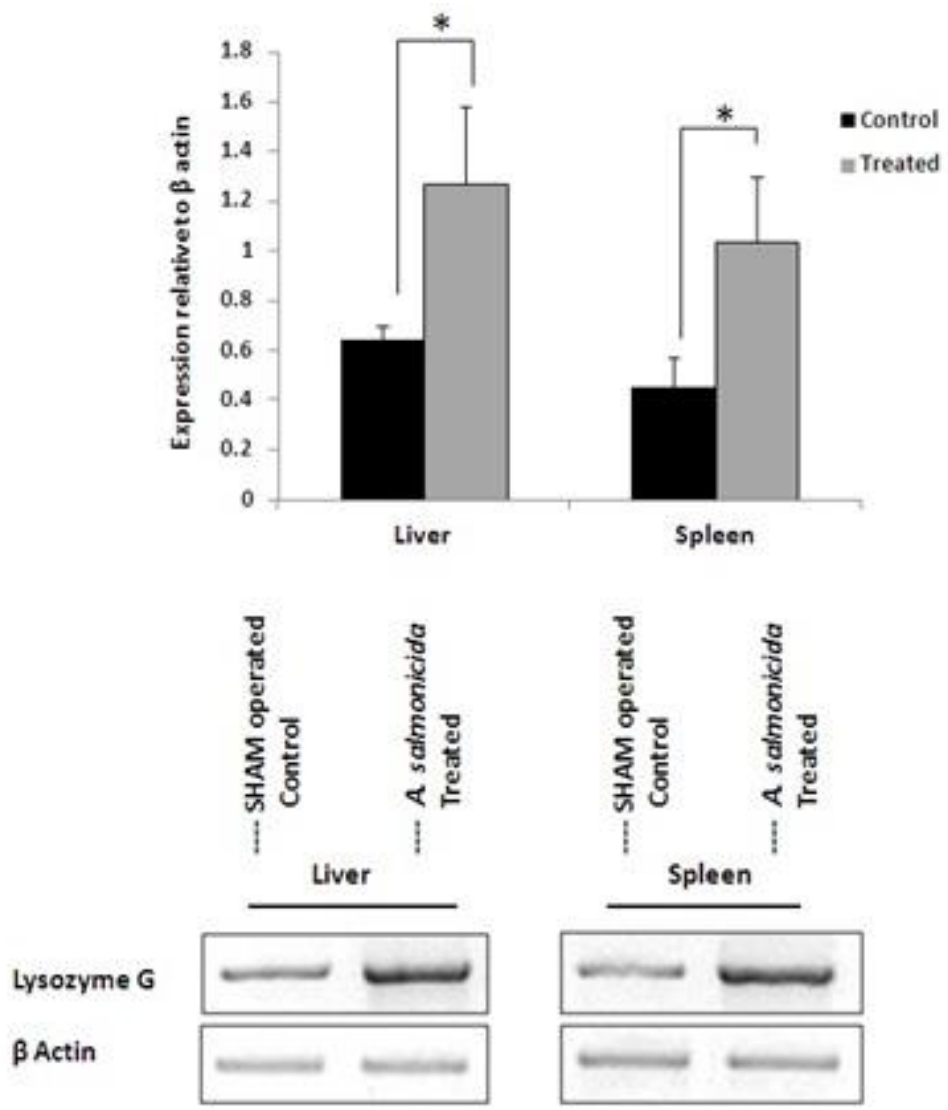

Figure 10. Differential Expression of Lysozyme $\mathrm{G}$ in liver and spleen of SHAM operated control and A. salmonicida infected $L$. rohita. *Significant $(\mathrm{P}<0.05)$. 
$1.01 \pm 0.07$; spleen $0.93 \pm 0.04$ ) and Lysozyme G (liver $0.64 \pm 0.06$; spleen $0.45 \pm 0.12$ ) respectively.

Histological examination in $L$. rohita liver and spleen, after $A$. salmonicida infection exhibited hepatic and splenic damage characterized by development of granulomatous inflammation, aggregation of melanomacrophage centres (MMC) and other considerable modifications i.e. ruptured and irregular cells, granulation in cytoplasm, necrosis, rupturing and cytolysis of hepatocytes (Figure 11) structural damage of connective tissue and necrosis of splenic pulp (Figure 12).

Figure 13 depicted the induction of apoptosis by Annexin V- FITC / PI staining in liver and spleen of control and $A$. salmonicida infected $L$. rohita. Significant $(P<0.05)$ increase in the percentage of early apoptotic cells $(18.2 \pm 0.12 \%)$ and late apoptotic cells $(0.5 \pm 0.08 \%)$ were observed in liver of infected fish in comparison to control samples (early apoptotic: $5.0 \pm 0.21 \%$; late apoptotic: $0.205 \pm 0.05 \%)$. The normal cells $(81.3 \pm 0.56$ $\%)$ decreased significantly in the infected fishes compared to control $(87.2 \pm 0.25 \%)$. A similar trend was also observed in the spleen of infected fishes where early apoptotic cells $(17.11 \pm 0.16 \%)$ and late apoptotic cells $(0.51 \pm 0.08 \%)$ increased significantly $(P<0.05)$ when compared to the control (early apoptotic: $11.0 \pm 0.11 \%$; late apoptotic: $0.23 \pm 0.02 \%)$. The normal cells $(82.18 \pm 0.72 \%)$ in spleen also decreased in the treated fishes in comparison to the control $(83.0 \pm 0.21 \%)$, in a pattern similar to that of fish liver.

Relative gene expression analysis of Caspase 3 gene was studied by semi quantitative reverse transcriptase PCR after isolation of total RNA from liver and spleen, which exhibited a significant increase in the expression of Caspase 3 in the $A$. salmonicida infected fishes compared to SHAM operated control fishes both
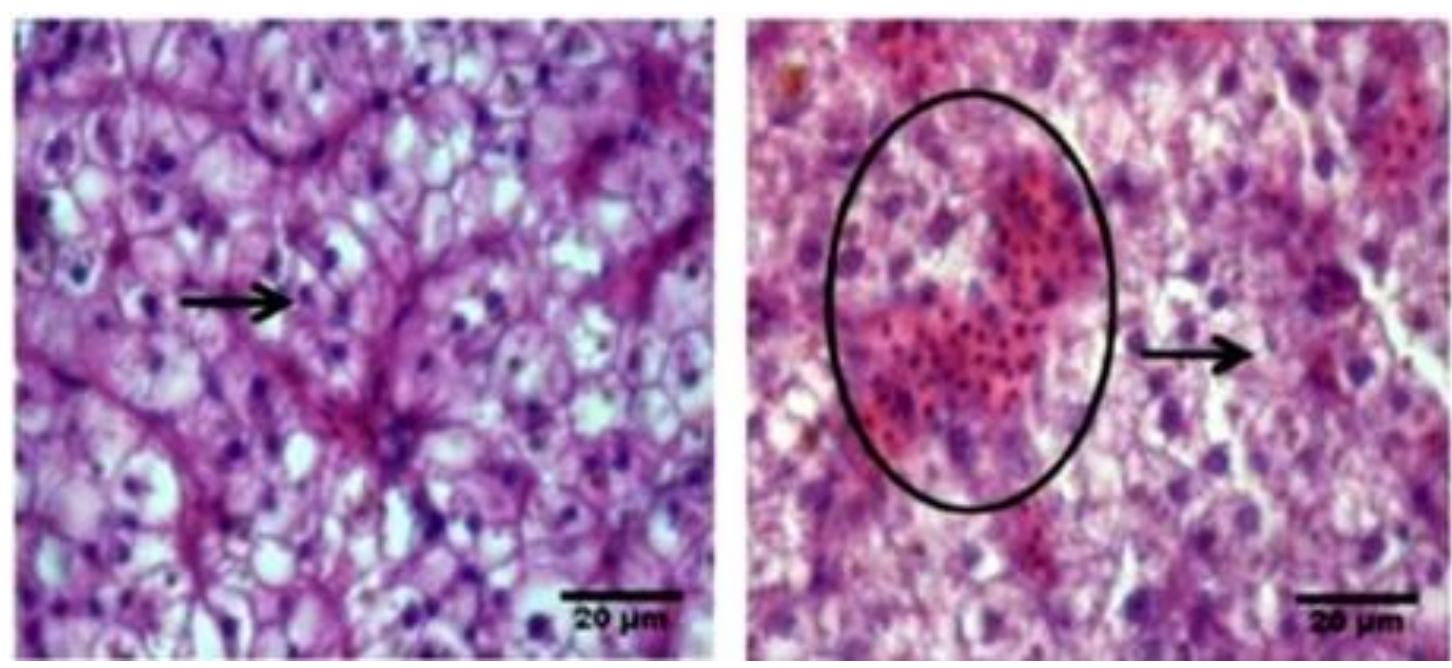

Figure 11. Histopathology of control liver (Figure A) and liver in the A. salmonicida (Figure B) infected L. rohita after 7 days of exposure. [x 400]. Figure A: depicting normal tissue architecture with compact hepatocytes (marked by arrow). Figure B: clearly showing bacterial infestation (marked by circle) and tissue damage (marked by arrow).
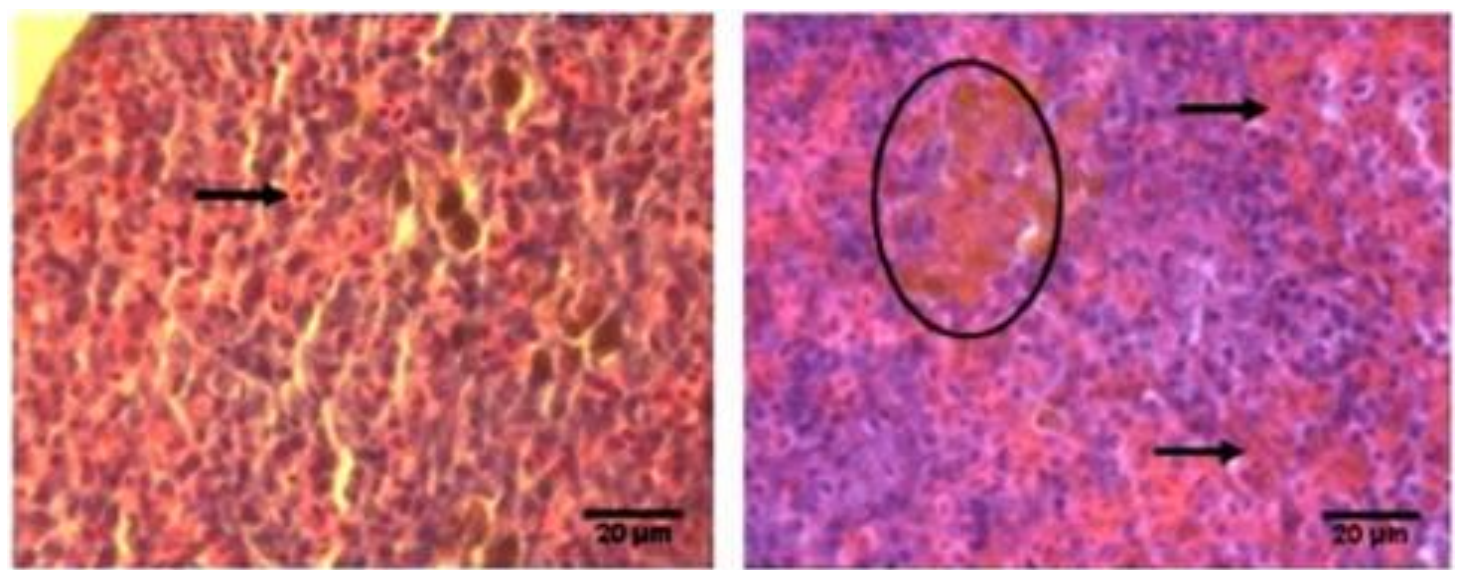

Figure 12. Histopathology of control spleen (Figure A) and A. salmonicida (Figure B) infected L. rohita after 7 days of exposure. [x 400]. Figure A: depicting normal tissue architecture with compact splenocytes (marked by arrow). Figure B: clearly showing bacterial infestation (marked by circle) and tissue damage (marked by arrow). 
in liver and spleen (Figure 14). In case of liver a significantly $(P<0.05)$ higher value of Caspase 3 expression was observed in $A$. salmonicida infected fishes $(1.57 \pm 0.11)$ compared to control fishes $(0.58 \pm 0.05)$. Similar trend was also observed in case of spleen, where significantly $(\mathrm{P}<0.05)$ higher value was found in $A$. salmonicida infected fishes $(1.30 \pm 0.28)$ in comparison to control fishes $(0.56 \pm 0.12)$ (Figure 14).
Finally, to confirm the fact that successful establishment of the infection was caused by the bacterial pathogen $A$. salmonicida and also to conclusively state that all the changes evident in the present study have occurred due to the pathogen, reisolation of the bacterial colonies from the fish tissue was targeted. Presumptive identification of $A$. salmonicida was carried out by several biochemical

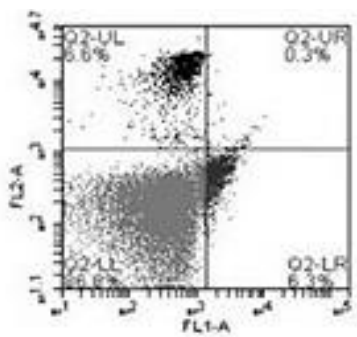

Liver (Control)

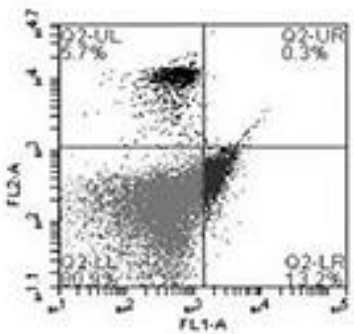

Spleen (Control)

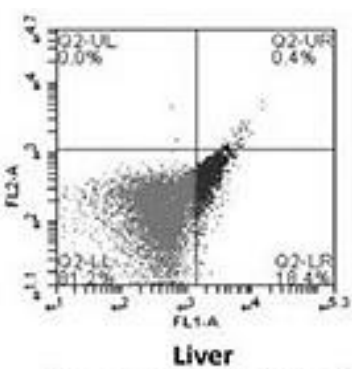

(A. salmonicida treated)

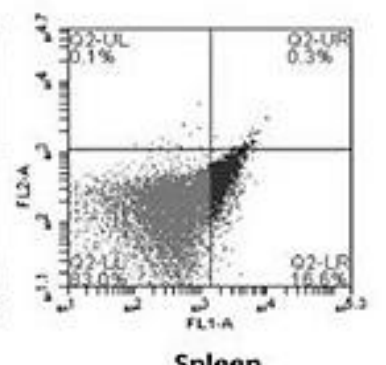

Spleen
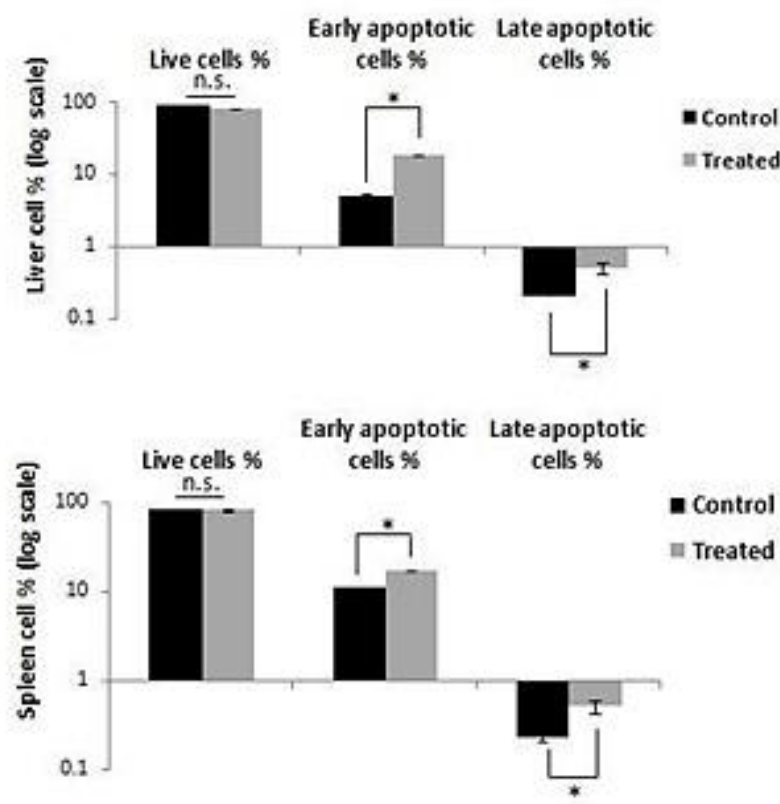

(A. salmonicida treated)

Figure 13. Cell death analysis by FITC - Annexin V /PI study in liver and spleen of control and A. salmonicida infected L. rohita. *Significant $(\mathrm{P}<0.05)$.

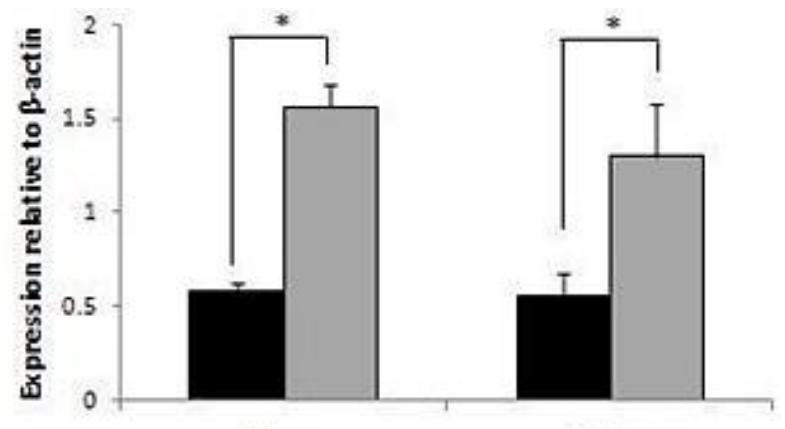

Spleen
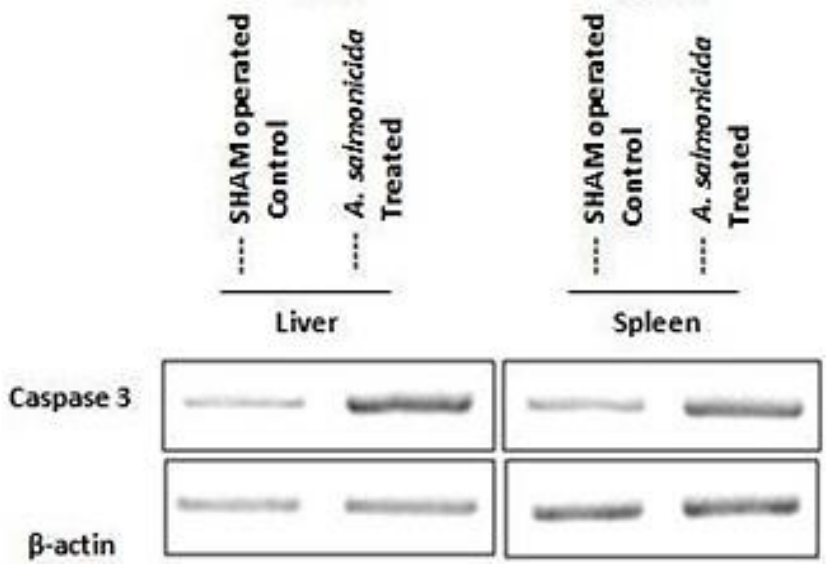

Figure 14. Differential Expression of Caspase 3 in liver and spleen of SHAM operated control and A. salmonicida infected $L$. rohita. *Significant $(P<0.05)$. 
tests. At 7 DPI tissue homogenates were prepared from liver and spleen of the clinical isolates and inoculated and plated onto different selective, biochemical growth media viz. MacConkey agar, CBB agar and TSA for confirmation (Figure 15) following Teska, \& Cipriano (1993), Popoff (1984), Wiklund, \& Bylund (1993). Production of brownish diffused pigment (Figure 15A), bluish colonies (Figure 15B) and yellowish colonies (Figure $15 \mathrm{C}$ ) respectively in TSA, CBB and MacConkey agar indicated and confirmed $A$. salmonicida to be present in the treated fish after 7 days of artificial challenge study and successful re-isolation of the bacterial pathogen.

Further confirmation, at molecular level was performed by PCR amplification with DNA isolated from presumptive $A$. salmonicida, using 4 pairs of primers viz. AP1/AP2, PAAS1/PAAS2, MIY1/MIY2 \& 16S rRNA. After gel electrophoresis the PCR products were observed under an UV transilluminator (Figure 16) and identification of $A$. salmonicida was confirmed with observation of specific bands at length $421 \mathrm{bp}, 423 \mathrm{bp}$, 512 bp and 1465 bp respectively as per Mooney, Powell, Clabby, \& Powell (1995).

\section{Discussion}

The trend of haematological and serum biochemical parameters observed in our earlier studies (Pal, Datta Roy \& Homechaudhuri, 2015) suggested that alterations in these parameters could be used as potential exposure biomarkers for Aeromonad infection at asymptomatic level. As per our earlier reports $L$. rohita injected with asymptomatic dose of $A$. salmonicida showed no external and internal lesion of the diseases even after 7 days of exposure. But significant alterations in fish heath indicators viz. haematological and serum biochemical parameters in comparison to control fishes indicated successful establishment of the bacterial infection within the fish body (Pal, \& Homechaudhuri, 2016). In the present
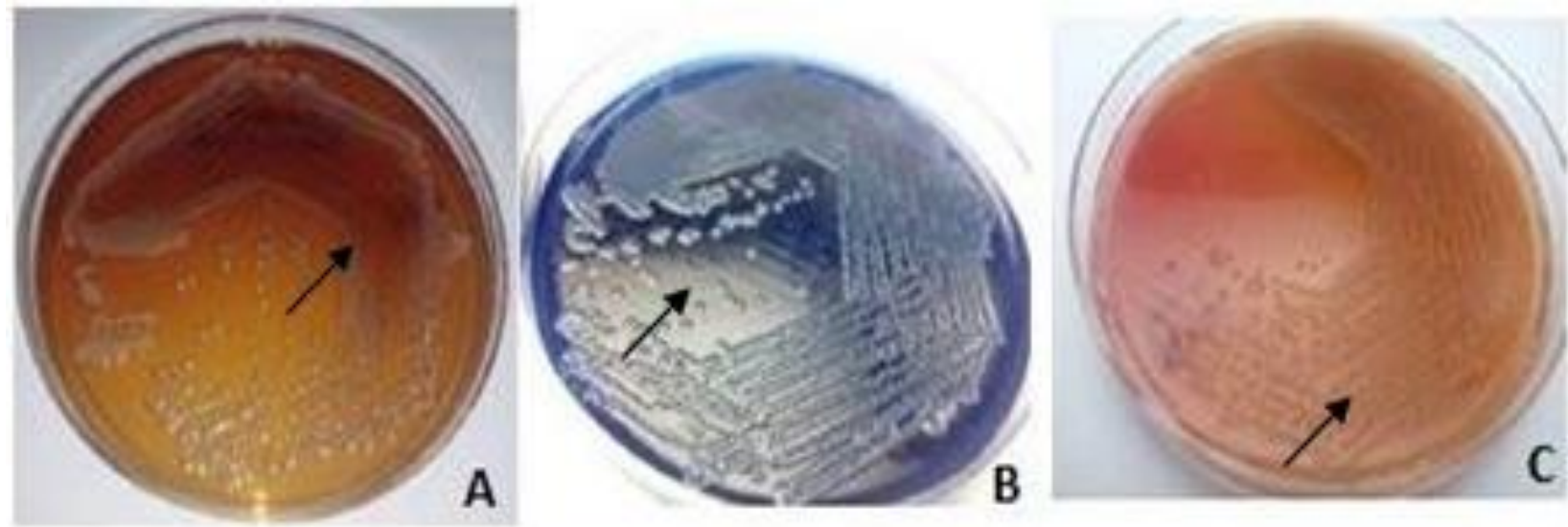

Figure 15. Re-isolation and confirmation of $A$. salmonicida from clinical isolates by biochemical tests. Fig 16A. Production of brown soluble pigment in TSA; Fig 16B. Bluish colonies in CBB agar; Fig 16C. Yellowish colonies in MacConkey agar all indicating $A$. salmonicida culture isolated from infected fish tissue after 48 hours incubation at $22^{\circ} \mathrm{C}$.

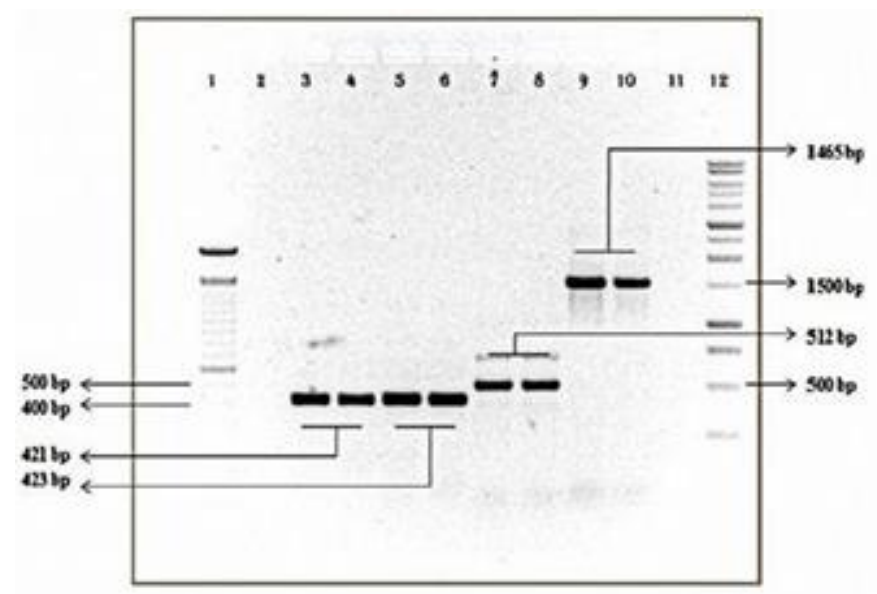

\begin{tabular}{|l|l|}
\hline Lane 1: & 100 bp DNA ladder (Fermentas) \\
\hline Lane 2 \& 11: & PCR negative control \\
\hline $\begin{array}{l}\text { Lane 3,5,7 \& } \\
\text { 9: }\end{array}$ & $\begin{array}{l}\text { PCR product from DNA isolated from } \\
\text { colonies of Aeromonas sabmonicida in } \\
\text { TSA plate }\end{array}$ \\
\hline $\begin{array}{l}\text { Lane 4,6, \& \& } \\
\text { 10: }\end{array}$ & $\begin{array}{l}\text { PCR product from DNA isolated from } \\
\text { Aeromonas saimonicida }\end{array}$ \\
\hline Lane 12: & 1 kb DNA ladder(Fermentas) \\
\hline
\end{tabular}

Figure 16. Aeromonas salmonicida (ATCC 33658) showing products obtained from primer for AP1/AP2 (421 bp), PAAS1/PAAS2 (423 bp), MIY1/MIY2 (512 bp) \& 16S rRNA (1465 bp). 
study, haematological parameters (TLC, MCV, MCH, $\mathrm{MCHC}$ ) and serum biochemical parameters (total serum protein and serum glucose level) were studied over three different exposure durations and it was found that these parameters varied most significantly in the treatment groups at $7 \mathrm{DPI}$. The treatment groups also exhibited an overall decrease in all these values when compared to the control groups over the period of 21 days. The significant increase in the total WBC count after bacterial infection observed in this study signified the fact that the innate immunity of the fish was stimulated to fight against the injected bacterial pathogen as the primary line of defense. The increased level of serum total protein observed in this current study could be an indication of elevated level of functioning of nonspecific immune response of fishes against the bacterial infection, as the serum proteins include various humoral elements of the non-specific immune system. Similar observations were also reported by several authors (Rehulka, \& Minarík, 2005; Zhou, Li, Abbas, \& Wang, 2009; Singh, Singh, Bhartiya, \& Yadav, 2010). Significant increase in serum glucose level in $A$. salmonicida infected fishes compared to control fishes was primarily due to acute stress caused by bacterial infection where mobilization of readily available energy in the form of glucose enhanced the survival of fish and helped to ward off the infection induced stress. After the initial screening of the abovementioned parameters in $L$. rohita against $A$. salmonicida infection at a carrier state it was found that the immune reaction and resultant stress was most prominently exhibited at 7 DPI in comparison to 14 and $21 \mathrm{DPI}$. As the objective of the current study was to provide an insight on the immune system functioning of L. rohita in response to $A$. salmonicida infection and also to provide an overview on the disease mechanisms, thus further detailed studies on the immune response at cellular and molecular level have been targeted at 7 DPI only.

In fish, phagocytosis has been recognized as one of the important elements in the host defense against invading micro-organisms (MacArthur, \& Fletcher, 1985) and constitutes an important characteristic of the innate immune system (Seeley, Gillespie, \& Weeks, 1990). The NBT assay is a very good indicator of the health status of fish and further indicative of oxidative radical production from neutrophils and monocytes for use in defense against pathogens (Anderson, Moritomo, \& de Grooth,1992; Anderson, \& Siwicki, 1995). The significantly higher number of NBT-positive cells i.e. cells with dark bluish formazan deposit within the cytoplasm observed in the current study indicated that upon pathogenic bacterial infection, the phagocytic activity and respiratory burst activities of neutrophils were significantly induced due to the innate immune system functioning.

Myeloperoxidase (MPO) is an important enzyme which utilizes hydrogen peroxide during respiratory burst to produce hypochlorous acid acting as antimicrobial agent (Dalmo, Ingebrigsten, Sveinbjornsson, \& Seljelid, 1996). An increased MPO activity was recorded in the neutrophil population of $L$. rohita infected with $A$. salmonicida at asymptomatic levels in comparison to sham operated control fishes in the present study. Several authors have documented similar changes in fish exposed to different pathogens (Sahoo et al., 2004; Rodríguez, Novoa, \& Figueras, 2008; Raida, \& Buchmann, 2008; 2009; Mohanty, \& Sahoo, 2010).

TNF $\alpha$ is mainly involved in the recruitment of leukocytes to the inflammatory foci rather than in their activation (Roca et al., 2008). The results indicated that A. salmonicida infection, even at asymptomatic carrier stage, might modulate the host immunity as relative expression of TNF $\alpha$ gene was found to be significantly up-regulated both in liver and spleen tissue of $L$. rohita post infection in comparison to sham operated control fishes. The expression levels were normalized with $\beta$ actin as internal control to avoid any errors in the initial RNA concentration. The cytokine TNF- $\alpha$ is one of the crucial mediators of pro inflammatory responses (Hanington, Hitchen, Beamish, \& Belosevic, 2009). Similarly, up-regulation of TNF $\alpha$ differential expression have been reported in rainbow trout leucocytes in response to different pro-inflammatory stimuli (Hardie, Chappell, \& Secombes, 1994; Iliev, Liarte, MacKenzie, \& Goetz, 2005).These findings pointed out that at 7 DPI with $A$. salmonicida, the innate immune system of $L$. rohita was significantly stimulated in terms of respiratory burst activity and a pro-inflammatory response was also initiated at major immune competent organs like liver and spleen.

The increased non-specific immune response in terms of serum bactericidal activity in the present study was a result of pathogen detection and activation of innate system. These results w.r.t. serum bactericidal activities were in accordance with various studies on different fish species (Hernandez, Teshima, \& Koshio, 2007; Aly, Ahmed, Ghareeb, \& Mohamed, 2008; Rao, Das, Jyotyrmayee, \& Chakrabarti, 2006; Misra, Das, \& Mukherjee, 2009; Das, Pradhan, \& Sahu, 2009).

Lysozyme, an important defence molecule, is one of the several antimicrobial enzymes, associated with the first line immune defense of both invertebrates and vertebrates playing a role in mediating protection against microbial invasion. It is bactericidal in nature that catalyzes the hydrolysis of $\beta-1,4$ linked glycoside bonds of peptidoglycan layer resulting in lysis of bacterial cell wall (Brown et. al., 1997). In the present study, relative expression of lysozyme $C$ was found to be significantly increased in liver and spleen tissue of $L$. rohita. Similar pattern was also observed in case of lysozyme $G$ where significant increase was observed both in liver and spleen of infected fishes when compared to control ones. Also, liver exhibited the higher degree of up-regulation in the expression of these genes compared to spleen. 
Histological sections of liver and spleen in $A$. salmonicida infected $L$. rohita when examined under microscopy at 7 DPI indicated significant alteration and modification of normal tissue architecture, induced by oxidative stress were observed. Similar type of tissue destructions in the liver and spleen were also reported in several instances viz. in I. punctatus (Ventura \& Grizzle, 1988), Clarius batracus (Angka, 1990), Salmo gairdneri (Candan, 1990), estuarine Cat fish (Alagappan, Deivasigamani, Kumaran, \& Shaktivel, 2009), Cirrhinus mrigala (Datta Ray \& Homechaudhuri, 2014) and Catla catla (Datta Ray \& Homechaudhuri, 2013) post infection with $A$. hydrophila. However, the spleen was found to be less susceptible than liver in terms of histological alterations in the present study.

Since significant cellular damage and death in liver and spleen were observed at the histopathology level, further study to ascertain the nature of such reported cell death by the Annexin V - FITC/ PI study was employed. In this study, $A$. salmonicida infection resulted in significantly higher values of early and late apoptotic cell percentage both in liver and spleen compared to control fishes. The finding was in accordance with results obtained in histopathological observations earlier. Similar studies in Cirrhinus mrigala challenged with $A$. hydrophila showed results in support of the present findings (Datta Ray \& Homechaudhuri, 2014), thus indicating that production of intracellular ROS (liver > spleen) takes place in an organ specific pattern and that excess ROS is a potent inducer of apoptotic cell death.

Consequently, it was aimed to determine the fate of caspase-3 gene expression in L. rohita upon infection with A. salmonicida. PCR analysis of the CDNA prepared from liver and spleen using primers designed for Caspase- 3 resulted in a 285 bp product. From the results obtained it was found that in the liver and spleen tissue the expression levels showed a significant increase after infection with A. salmonicida in comparison to the control fishes. Activated caspase-3 is a central effector of apoptosis that cleaves and inactivates a number of molecules contributing to the typical morphology of apoptosis (Wolf \& Green, 1999; Fischer, Jänicke \& Schulze-Osthoff, 2003). Increased gene expression of caspase- 3 has been described earlier in cells under apoptosis (Miller et al. 1997, Chiang et al. 2001). In this case, it was obvious that upon bacterial infection and subsequent ROS production the caspase-3 mRNA levels shot up significantly in order to meet the increasing demand for the execution of apoptosis.

\section{Conclusion}

The overall results obtained from the present study indicated that exotic, invasive pathogen $A$. salmonicida infection at an asymptomatic, carrier state acted as strong physiological stressors for L. rohita fingerlings resulting in the activation of alarm-stress response leading to deterioration of health status. It induced oxidative stress related inflammation and ultimately resulted in apoptotic cell death both in liver and spleen (Liver > Spleen). Expression of antimicrobial protein producing genes (Lysozyme $\mathrm{C}$ and Lysozyme $\mathrm{G}$ ), proinflammatory cytokine (TNF $\alpha)$ producing gene and expression of apoptosis effector molecule (Caspase 3 ) were also found to be significantly higher both in liver and spleen of $A$. salmonicida treated fishes compared to control ones. From the overall findings, it could be stated that a multi parametric bio-marker approach for evaluating the pathogenic and physiological impact of Aeromonas infection can be highly convenient in $L$. rohita, especially at a carrier state dose i.e. without obvious symptomatic manifestation of the disease.

Since facultative pathogen eradication is not possible in open water or flow-through aquaculture systems, this remains a crucial area of scientific research and the results obtained in the present study might provide a better understanding of prophylactic, diagnostic and therapeutic measures during aquaculture.

\section{Acknowledgements}

The authors are grateful to the Department of Zoology, University of Calcutta, West Bengal, India for providing the facilities to carry out the research work. This study was funded by the Science and Engineering Research Board (SERB), Department of Science and Technology (DST), Government of India SSanction No: SR/SO/AS - 067/2014. The senior research fellowship [UGC/492/Jr. Fellow (Upgradation)] by the University Grants Commission to the first author is thankfully acknowledged.

\section{References}

Alagappan, K.M., Deivasigamani, B., Kumaran, S., \& Shaktivel, M. (2009). Histopathological alterations in Estuarine catfish (Arius maculatus, Thunberg, 1972) due to Aeromonas hydrophila infection. World Journal of Fish and Marine Sciences, 1(3), 185-189.

Almeida, A., Cunha, Â., Gomes, N., Alves, E., Costa, L., \& Faustino, M.A. (2009). Phage therapy and photodynamic therapy: low environmental impact approaches to inactivate microorganisms in fish farming plants. Marine Drugs. 7(3), $268-313$. https://doi.org/10.3390/md7030268

Aly, S.M., Ahmed, Y.A.; Ghareeb, A.A.A., Mohamed, M.F. (2008). Studies on Bacillus subtilis and Lactobacillus acidophilus, as potential probiotics, on the immune response and resistance of Tilapia nilotica (Oreochromis niloticus) to challenge infections. Fish and Shellfish. Immunology, 25, 128- 136.

Anderson D.P., Moritomo T., \& de Grooth, R. (1992). Neutrophil, glass-adherent, nitro blue tetrazolium assay gives early indication of immunization effectiveness in rainbow trout. Veterinary Immunology and Immunopathology, 30, 419-429.

https://doi.org/10.1016/0165-2427(92)90110-C 
Anderson, D.P., \& Siwicki, A.K. (1995). Basic haematology and serology for fish health programs. In: Diseases in Asian aquaculture II. M. Shariff, J., Arthur, R., \& Subasinghe, R. P.(Eds). Fish Health Section, Asian Fisheries Society, Manila, Philippines. 185-202.Angka, S. L. (1990). The pathology of the walking Catfish, Clarias batrachus (L.) infected intraperitoneally with $A$. hydrophila. Asian Fisheries Science, 3, 343-351.

Arkoosh, M.R., Clemons, E., Kagley, A.N., Stafford, C., Glass, A.C., Jacobson, K., Reno, P., Myers, M.S., Casillas, E., Loge, E., Johnson, L.L. \& Collier, T.K. (2004). Survey of pathogens in juvenile salmon Oncorhynchus spp. migrating through Pacific northwest estuaries. Journal of Aquatic Animal Health, 16(4), 186-196. https://doi.org/10.1577/H03-071.1

Arthur, J. R. (2005) A historical overviews of pathogen introductions and their transboundary spread in Asia. Preparedness and response to aquatic animal heath emergencies in Asia. FAO Rome, Italy. FAO Fisheries Technical paper. 451, 1-71.

Bernoth, E.M., Ellis, A., Midtlyng, P., Olivier, G., \& Smith, P. (1997). Furunculosis Multidisciplinary Fish Disease Research, 1st edn. Academic Press, San Diego, CA.

Brown, L.L., Cox, W.T., \& Levine, R.P. (1997). Evidence that the causal agent of bacterial cold-water disease Flavobacterium psychrophilum is transmitted within salmonid eggs. Diseases of Aquatic Organisms, 29, 213218.

Candan, A.A. (1990). A Study on the histopathology of $A$. hydrophila infections of rainbow trout (Salmo gairdneri R.) kept under experimental conditions and the effect of chloramphenicol. Journal of Aquatic Food Product Technology, 4, 5-20.

Chiang, L.W., Grenier, J.M., Ettwiller, L., Jenkins, L.P., \& Ficenec, D. (2001). An orchestrated gene expression component of neuronal programmed cell death revealed by CDNA array analysis. Proceedings of the National Academy of Sciences USA, 98. 2814-2819. http://www.pnas.orgycgiydoiy10.1073ypnas.05163059 8

Cipriano, R.C., \& Bullock. G.L. 2001. Furunculosis and other diseases caused by Aeromonas salmonicida. United States Geological Survey. Fish Disease Leaflet, 66. 33.

Crane, M., \& Hyatt, A. (2011). Viruses of Fish: An Overview of Significant Pathogens. Viruses. 3(11), 2025-2046. https://doi.org/10.3390/v3112025

Dacie, J.V., \& Lewis, S.N. (1984). Practical Haematology. 6th Edn, Edindurg: Churchill Livingstone, 405-411.

Dalmo, R.A., Ingebrigsten, K., Sveinbjornsson, B., \& Seljelid, R. (1996). Accumulation of immunomodulatory laminaran (beta (1,3)-D-glucan) in the heart, spleen and kidney of Atlantic cod, Gadus morhua. Journal of Fish Diseases.19, 129-136.https://doi.org/10.1111/j.13652761.1996.tb00691.x

Das, B.K., Pradhan, J., \& Sahu, S. (2009). The effect of Euglena viridis on immune response of rohu, Labeo rohita (Ham.). Fish and Shellfish Immunology, 26, 871-876.

Datta Ray, S., \& Homechaudhuri, S. (2013). Non-specific Immune Response in Indian Major Carp, Catla catla against Aeromonas hydrophila Infection. Science and Culture, 79 (11-12), 507-511.

Datta Ray, S., \& Homechaudhuri, S. (2014). Morphological and functional characterization of hepatic cells in Indian major carp, Cirrhinus mrigala against Aeromonas hydrophila infection. Journal of Environmental Biology, 35(1), 253.

Deivasigamani, B. (2008). The immune response in catfish, Mystus gulio. Journal of environmental biology / Academy of Environmental Biology, India, 29, 863-866.

Dorsch, M., \& Stackebrandt, E. (1992). Some modifications in the procedure of direct sequencing of PCR amplified $16 \mathrm{~S}$ rDNA. Journal of Microbiological Methods, 16(4), 271279. https://doi.org/10.1016/0167-7012(92)90017-X

Evenberg, D. \& Lugtenberg, B., (1982). Cell surface of the fish pathogenic bacterium Aeromonas salmonicida II. Purification and characterization of a major cell envelope protein related to autoagglutination, adhesion and virulence. Biochimica et Biophysica Acta., 684, 249254.

FAO. (2018). The State of Food Security and Nutrition in the world. Building climate resilience for food security and nutrition. Food and Agriculture Organization of the United Nations. Rome, Italy.

Fischer, U., Jänicke, R.U., \& Schulze-Osthoff, K. (2003). Many cuts to ruin: a comprehensive update of caspase substrates. Cell Death and Differentiation, 10, 76-100. http://dx.doi.org/10.1038/sj.cdd.4401160 22

Gómez-Ochoa, P., Sabate, D., Homedes, J., \& Ferrer, L. (2012). Use of the Nitroblue tetrazolium reduction test for the evaluation of Domperidone effects on the neutrophilic function of healthy dogs. Veteinary Immunology and Immunopathology. 146(1), 97-99. https://doi.org/10.1016/j.vetimm.2012.01.018.

Gustafson, C.E., \& Thomas, C.J. (1992). Detection of Aeromonas salmonicida from fish by using polymerase chain reaction amplification of the virulence surface array protein gene. Applied and Environmental Microbiology, 58(12), 3816-3825.

Hanington, P.C., Hitchen, S.J., Beamish, L.A., \& Belosevic, M. (2009). Macrophage colony stimulating factor (CSF-1) is a central growth factor of goldfish macrophages. Fish and Shellfish Immunology, 26(1), 1-9. 10.1016/j.fsi.2008.09.020.

Hardie, L.J., Chappell, L.H., \& Secombes, C.J. (1994). Human tumor necrosis factor [alpha] influences rainbow trout Oncorhynchus mykis leucocyte responses. Veterinary Immunology and Immunopathology, 40(1), 73-84. https://doi.org/10.1016/0165-2427(94)90016-7

Hernandez, L.H.H., Teshima, S., \& Koshio, S. (2007). Effects of vitamin $\mathrm{A}$ on growth, serum anti-bacterial activity and transaminase activities in the juvenile Japanese flounder, Paralichthys olivaceus. Aquaculture, 262, 444450.

Iliev, D.B., Liarte, C.Q., MacKenzie, S., \& Goetz, F.W. (2005). Activation of rainbow trout (Oncorhynchus mykiss) mononuclear phagocytes by different pathogen associated molecular pattern (PAMP) bearing agents. Molecular Immunology, 42(10),1215-1223. https://doi.org/10.1016/j.molimm.2004.11.023

MacArthur, J.I., \& Fletcher, T.C. (1985). Phagocytosis in fish. In: Manning, M. J., Tatner, M. F. eds. Fish Immunology. Academic Press. London. 29-46.

Martinez-Murcia, A.J., Soler, L., Jose Saavedra, M., Chacon, M.R., Guarro, J., Stackebrandt, E., \& Jose Figueras, M. (2005). Phenotypic, genotypic, and phylogenetic discrepancies to differentiate Aeromonas salmonicida from Aeromonas bestiarium. International Microbiology, 8, 259-269. 10.2436/im.v8i4.9534 
Miller, T.M., Moulder, K.L., Knudson, C.M, Creedon, D.J., \& Deshmukh, M. (1997). Bax deletion further orders the cell death pathway in cerebellar granule cells and suggests a caspase independent pathway to cell death. Journal of Cell Biology, 139, 205-217. https://doi.org/10.1083/jcb.139.1.205

Misra, C.K., Das, B.K., \& Mukherjee, S.C. (2009). Immune response, growth and survival of Labeo rohita fingerlings fed with levamisole supplemented diets for longer duration. Aquaculture Nutrition, 15, 356-365.

Miyata, M., Inglis, V., \& Aoki, T. (1996). Rapid identification of Aeromonas salmonicida subspecies salmonicida by the polymerase chain reaction. Aquaculture, 141(1-2), 1324.

Mohanty, B.R., \& Sahoo, P.K. (2010). Immune responses and expression profiles of some immune-related genes in Indian major carp, Labeo rohita to Edwardsiella tarda infection. Fish \& shellfish immunology, 28(4), 613-621. https://doi.org/10.1016/j.fsi.2009.12.025

Mooney, J., Powell, E., Clabby, C., \& Powell, R. (1995). Detection of Aeromonas salmonicida in wild Atlantic salmon using a specific DNA probe test. Diseases of Aquatic Organisms. 21, 131-135.

O'Brien, D., Mooney, J., Ryan, D., Powell, E., Hiney, M., Smith, P.R., \& Powell, R. (1994). Detection of Aeromonas salmonicida, causal agent of furunculosis in salmonid fish, from the tank effluent of hatchery reared Atlantic salmon smolts. Applied and Environmental Microbiology, 60(10), 3874- 3877.

Pal, J., \& Pradhan, K. (1990). Bacterial involvement in ulcerative condition of air- breathing fish from India. Journal of fish Biology, 36(6), 833-839. https://doi.org/10.1111/j.1095-8649.1990.tb05631.x

Pal, S., Datta, Ray, S., \& Homechaudhuri, S. (2015). Evaluation of in vivo non-specific immunity and oxidative stress in Labeo rohita (Hamilton, 1822) infected with Aeromonas hydrophila as biomarker for early diagnosis. International Journal of Fisheries and Aquatic Studies, 3(1): 116-124.

Pal, S., Datta, R. S., \& Homechaudhuri, S. (2016). Serum bactericidal activity as indicator of innate immunity in Labeo rohita (Hamilton, 1822) challenged with Aeromonas hydrophila as biomarker for clinical monitoring, International Journal of Advanced Research in Biological Sciences, 3(1): 134-144.

Pal, S., \& Homechaudhuri, S. (2016). Physiological responses to Aeromonas salmonicida infection in Labeo rohita (Hamilton, 1822): Effects on haematological, serum biochemical and nonspecific immune parameters. International Journal of Research in Fisheries and Aquaculture, 6(2): 68-74.

Popoff, M. (1984). Genus III Aeromonas Kluyver and van Niel 1936 398AL. In: Krieg, N. R., Holt, J. G., eds. Bergey's manual of systematic bacteriology, Vol. 1. Baltimore, MD, Williams \& Wilkins: 545-548.

Prokopowicz, Z., Marcinkiewicz, J., Katz, D. R., \& Chain, B. M. (2012). Neutrophil myeloperoxidase: Soldier and statesman. Archivum Immunologiae et Therapiae Experimentalis, 60, 43- 54. https://doi.org/10.1007/s00005-011-0156-8

Raida, M.K., \& Buchmann, K. (2008). Development of adaptive immunity in rainbow trout, Oncorhynchus mykiss (Walbaum) surviving an infection with Yersinia ruckeri. Fish \& Shellfish Immunology, 25(5), 533-541. https://doi.org/10.1016/j.fsi.2008.07.008
Raida, M.K., \& Buchmann, K. (2009). Innate immune response in rainbow trout (Oncorhynchus mykiss) against primary and secondary infections with Yersinia ruckeri 01. Developmental \& Comparative Immunology, 33(1), 3545. https://doi.org/10.1016/j.dci.2008.07.001

Rao, Y.V., Das, B.K., Jyotyrmayee, P., \& Chakrabarti, R. (2006). Effect of Achyranthes aspera on the immunity and survival of Labeo rohita infected with Aeromonas hydrophila. Fish and Shellfish Immunology, 20, 263-273.

Rehulka, J., \& Minarík, B. (2005). Blood parameters in brook trout Salvelinus fontinalis (Mitchill, 1815), affected by columnaris disease. Aquacultue Research, 38(11), 11821197.

Reyes, B.M., Salinas, I., Cuesta, A., Meseguer, J., Tovar, R. D., \& Ascencio, V. F. (2008). Oral delivery of live yeast Debaryomyces hansenii modulates the main innate immune parameters and the expression of immunerelevant genes in the gilthead seabream (Sparus aurata L.). Fish and Shellfish Immunology, 25, 433-438. https://doi.org/10.1016/j.fsi.2008.02.010

Roca, F.J., Mulero, I., Lopez-Munoz, A., Sepulcre, M.P., Renshaw, S.A., \& Meseguer, J. (2008). Evolution of the inflammatory response in vertebrates: fish TNF-alpha is a powerful activator of endothelial cells but hardly activates phagocytes. Journal of Immunology, 181(7), 5071-5081. https://doi.org/10.4049/jimmunol.181.7.5071

Rodríguez, I., Novoa, B., \& Figueras, A. (2008). Immune response of zebrafish (Danio rerio) against a newly isolated bacterial pathogen Aeromonas hydrophila. Fish and Shellfish Immunology, 25, 239-249 pp. https://doi.org/10.1016/j.fsi.2008.05.002

Sahoo, P.K., Meher, P.K., Mohapatra, K.D., Saha, J.N., Jana, R. K., \& Reddy, P.V.G.K. (2004). Immune responses in different fullsib families of Indian major carp, Labeo rohita, exhibiting differential resistance to Aeromonas hydrophila infection. Aquaculture, 238,15-125. https://doi.org/10.1016/j.aquaculture.2004.06.008

Sahoo, P.K., Mahapatra, K.D., Saha, J.N., Barat, A., Sahoo, M., Mohanty, B.R., Gjerde, B., Ødegård, J., Rye, M., \& Salte, R., (2008). Family association between immune parameters and resistance to Aeromonas hydrophila infection in the Indian major carp, Labeo rohita. Fish \& Shellfish Immunology. 25(1), 163-169. https://doi.org/10.1016/j.fsi.2008.04.003 26

Sambrook, J., Russell, D.W., \& Russell, D.W. (2001). Molecular cloning: a laboratory manual (3-volume set) (Vol. 999): Cold spring harbor laboratory press New York. Saurabh, S., \& Sahoo, P. K. (2008). Lysozyme: an important defence molecule of fish innate immune system. Aquaculture Research, 39, 223-239.

Seeley, K.R., Gillespie, P.D., \& Weeks, B.A. (1990). A simple technique for the rapid spectrophotometic determination of phagocytosis by fish macrophages. Marine Environmental Research, 30, 123-128.

Singh, A.P., Singh, S., Bhartiya, P. \& Yadav, K. (2010). Toxic effect of Phorate on serum biochemical parameters of Snake headed fish Channa punctatus (Bloch). Advances in bioresearch, 1(1), 177-181.

Teska, G.D., \& Cipriano, R.C. (1993). Nonselective nature of Coomassie Brilliant Blue agar for the presumptive identification of Aeromonas salmonicida in clinical specimens. Diseases of Aquatic Organisms, 16, 239 242. 
Ventura, M.T. \& Grizzle, J.M. (1988). Lesions associated with natural and experimental infections of Aeromonas hydrophila in channel catfish, Ictalurus puntatus Rafinesque. Journal of Fish Diseases, 11(5), $397-407$. https://doi.org/10.1111/j.1365-2761.1988.tb00735.x

Wiklund, T., \& Bylund, G. (1993). Skin ulcer disease of flounder Platichthys flesus in the northern Baltic Sea. Diseases of Aquatic Organisms, 17. 165-174.

Wolf, B.B. and Green, D.R. (1999). Suicidal tendencies: apoptotic cell death by caspase family proteinases. Journal of Biological Chemistry, 274, 20049-20052. 10.1074/jbc.274.29.20049.
Zar, J.H. (1999). Biostatistical analysis. 4th edn Prentice Hall. Upper Saddle River, New Jersey.

Zhou, X., Li, M., Abbas, K. \& Wang, W. (2009). Comparison of haematology and serum biochemistry of cultured and wild Dojo loach Misgurnus anguillicaudatus. Fish Physiology and Biochemistry, 35,435-441.

Zorrilla, I., Chabrillón, M., Arijo, S., Díaz- Rosales, P., MartínezManzanares, E., \& Balebona, M.C. (2003). Bacteria recovered from diseased cultured gilthead sea bream (Sparus aurata L.) in south western Spain. Aquaculture. 218, 11-20.

https://doi.org/10.1016/S0044-8486(02)00309-5 